\title{
Kingdom of Lesotho: First Review Under the Three-Year Extended Credit Facility Arrangement and Requests for Waiver of Nonobservance of Performance Criterion and Modification of Performance Criteria-Staff Report and Press Release.
}

In the context of the Kingdom of Lesotho First Review under the Three-Year Extended Credit Facility Arrangement and Requests for Waiver of Nonobservance of Performance Criterion and Modification of Performance Criteria, the following documents have been released and are included in this package:

- $\quad$ The staff report for the First Review Under the Three-Year Extended Credit Facility Arrangement and Requests for Waiver of Nonobservance of Performance Criterion and Modification of Performance Criteria, prepared by a staff team of the IMF, following discussions that ended on November 22, 2010, with the officials of Lesotho on economic developments and policies. Based on information available at the time of these discussions, and subsequent discussions during the preparation of the budget presented in mid-February 2011, the staff report was completed on March 18, 2011. The views expressed in the staff report are those of the staff team and do not necessarily reflect the views of the Executive Board of the IMF.

- $\quad$ An Informational Annex to the Staff Report of March 18, 2011.

- $\quad$ A Press Release containing factual statement on the completion of the review by the Executive Board and summarizing on the IMF arrangement.

The documents listed below have been or will be separately released.

Letter of Intent sent to the IMF by the authorities of Lesotho* Memorandum of Economic and Financial Policies by the authorities of the Kingdom of Lesotho* Technical Memorandum of Understanding*

*Also included in Staff Report

The policy of publication of staff reports and other documents allows for the deletion of market-sensitive information.

Copies of this report are available to the public from

International Monetary Fund • Publication Services

$70019^{\text {th }}$ Street, N.W. $\bullet$ Washington, D.C. 20431

Telephone: (202) 623-7430 • Telefax: (202) 623-7201

E-mail: publications@imf.org Internet: http://www.imf.org

\section{International Monetary Fund Washington, D.C.}




\section{INTERNATIONAL MONETARY FUND}

\section{KINGDOM OF LESOTHO}

\section{First Review Under the Three-Year Extended Credit Facility Arrangement and Requests for Waiver of Nonobservance of Performance Criterion and Modification of Performance Criteria}

Prepared by the African Department in Consultation with Other Departments

Approved by Domenico Fanizza and Tom Dorsey

March 18, 2011

- $\quad$ Extended Credit Facility arrangement. On June 2, 2010, the Executive Board approved a three-year ECF arrangement for SDR 41.88 million (120 percent of quota), against the backdrop of a sharp fall in revenues from the Southern African Customs Union (SACU). The shock requires a sizeable adjustment over the medium term to preserve fiscal and external sustainability.

- Discussions. The mission visited Maseru during November 10-22, 2010, where it met with Finance and Development Planning Minister Thahane, Central Bank of Lesotho Governor Senaoana, other senior government officials, and representatives of the donor community, the private sector and labour unions. Discussions continued during the preparation of the budget, presented in mid-February.

- Team. C. Daseking (head), M. Morgan, G. Pastor (all AFR), and C. Saborowski (SPR). Ms. Moloi (OED) also participated in a number of meetings.

- Review. The ECF-supported program is on track. All quantitative performance criteria for end-September 2010 were met, except for the floor on the stock of NIR which was missed by a small margin. Structural reforms are progressing, albeit with some delays. Staff supports the authorities' request for a waiver for the missed performance criterion and recommends completion of the first review under the ECF arrangement and modification of end-March 2011 performance criteria.

- Publication. The authorities have consented to publication of the staff report and the program documents. 


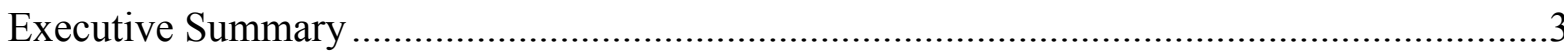

I. Recent Economic Developments and Outlook .......................................................4

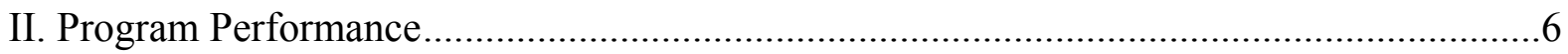

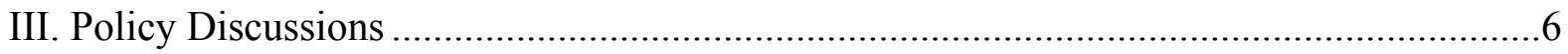

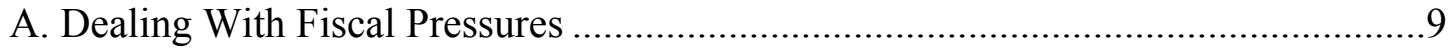

B. Mitigating Financial Sector Risk and Supporting Development ..........................11

C. Improving Productivity and the Investment Climate ...................................... 12

IV. Program Monitoring and Safeguards Assessment ..................................................13

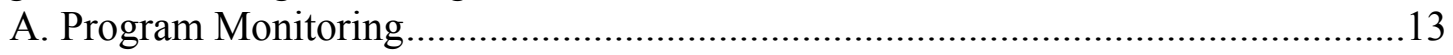

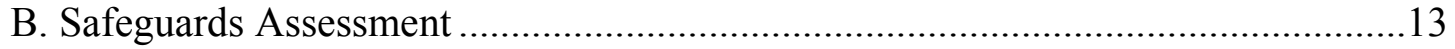

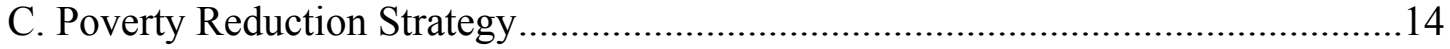

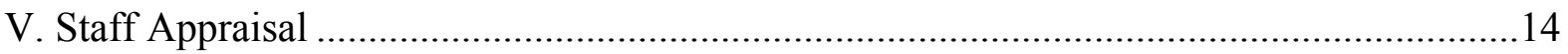

Tables

1. Selected Economic and Financial Indicators, 2008-15 ............................................... 16

2. Central Government Operations, 2009/10-2015/16................................................. 17

3. Central Government Operations, 2009/10-2015/16 ...................................................18

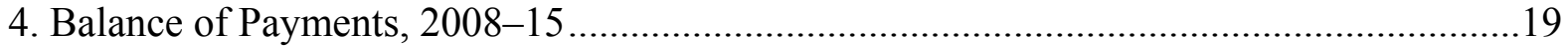

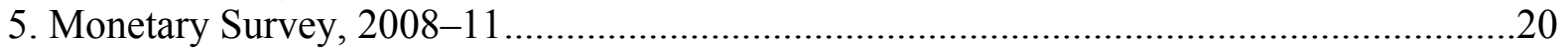

6. Schedule of ECF Disbursements and Reviews, 2011-13 ............................................21

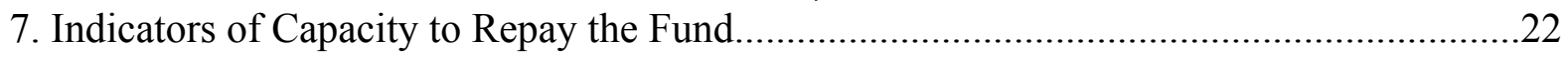

Figure

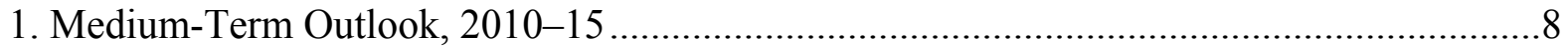

Box

1. Improving Public Financial Management............................................................... 10

Attachments

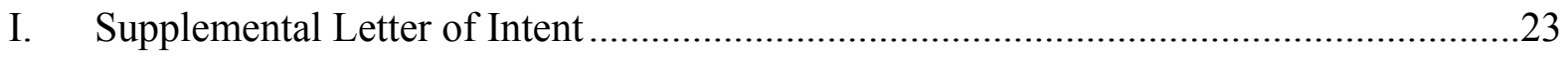

II. Supplemental Memorandum of Economic and Financial Policies 2010-12 _................25

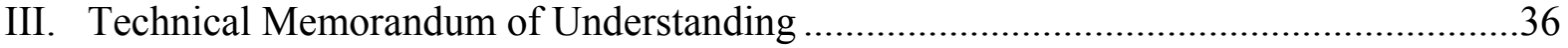




\section{EXECUTIVE SUMMARY}

Macroeconomic developments and prospects. While the impact of the global crisis on economic growth was milder than anticipated, the recovery is weaker, too. Real GDP growth is estimated at $2 \frac{1}{2}$ percent in 2010 , versus $5 \frac{1}{2}$ percent under the program. The external current account deficit has deteriorated to an estimated 16 percent of GDP, reflecting a sharp drop in SACU revenues and a weakening of the trade balance, affected by a strong loti/rand. Thanks to a revenue windfall of some 6 percent of GDP and adherence to tight expenditure ceilings, the 2010/11 fiscal deficit is now projected at 81/4 percent of GDP, versus 19 percent of GDP under the program.

Program Performance. The program is on track:

- All quantitative performance criteria for end-September 2010 were met, except for the floor on net international reserves (NIR) which was missed by a small margin.

- While most structural reform measures were implemented, some of the benchmarks were met with delay. The submission to Parliament of a new Financial Institutions Bill is now included as a benchmark for the second review.

Discussions. With the medium-term outlook broadly unchanged, program discussions focused on the budget for 2011/12 and the authorities' structural reform agenda.

- Budget for 2011/12. The mission agreed with the government on policies that would contain the overall deficit at 15 percent of GDP. Revenues, which were boosted by one-off transfers in 2010/11, are projected to fall by some 4 percent of GDP, while spending would rise by $23 / 4$ percent of GDP, reflecting both higher capital and current spending. The latter combines an increase in the wage bill-including from the adoption of a new pay scale for teachers; the financing of elections; and higher interest payments on domestic debt, with a reduction of about 2 percentage points of GDP in other primary current spending.

- Structural reforms. The authorities remain committed to their structural reform agenda, including financial sector reforms to reduce vulnerabilities and deepen financial intermediation, and measures to improve the business climate.

Recommendations. Staff supports the authorities' request for a waiver for non-observance of the end-September 2010 performance criterion on the floor on net international reserves and the modification of the end-March 2011 performance criteria, and recommends completion of the first review. 


\section{RECENT ECONOMIC DEVELOPMENTS AND OUTLOOK}

\section{Lesotho faces large fiscal and external imbalances due to a sharp drop in SACU} revenues. The reduction is particularly pronounced in 2010/11 and 2011/12, after which

SACU revenues are expected to stabilize at a permanently reduced level. ${ }^{1}$ Against this background, the authorities have adopted an ambitious medium-term adjustment program, supported by the ECF, which is focused on fiscal consolidation and growth-enhancing structural reforms to preserve fiscal and external sustainability, while maintaining the exchange rate peg to the South African rand.

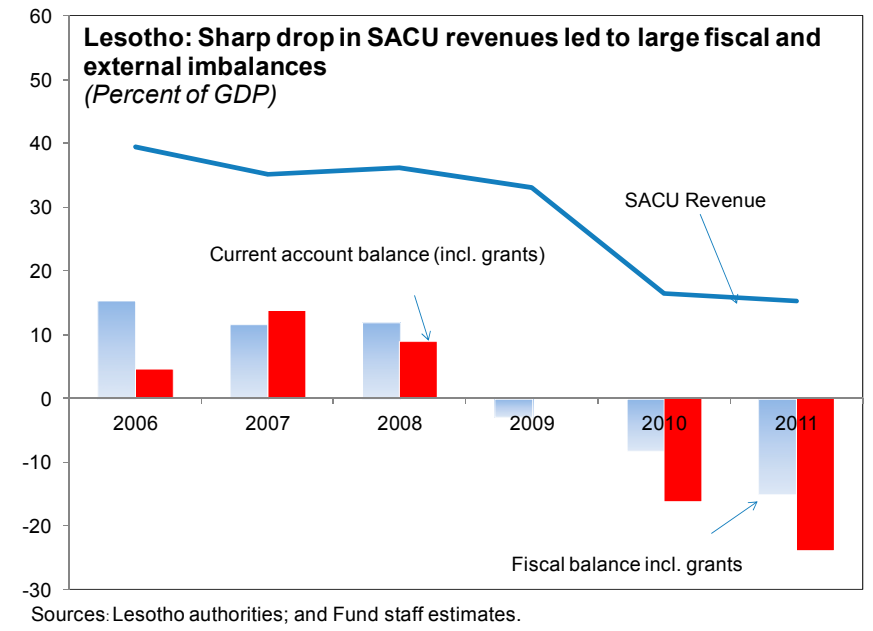

2. The macroeconomic conditions remains challenging. While the impact of the global crisis on economic growth was milder than expected, the recovery is weaker, too:

- Real GDP is estimated to have grown by $2 \frac{1 / 2}{2}$ percent in 2010 , considerably lower than the $5 \frac{1}{2}$ percent projected under the program. Growth was weakened by delays in implementing the Metolong Dam project and a fall in textile exports. The sector, which is Lesotho's main foreign exchange earner and its largest employer outside of government, was already suffering from declining demand in the U.S. and came under additional pressure from a significant appreciation of the loti/rand, which has since been partially reversed.
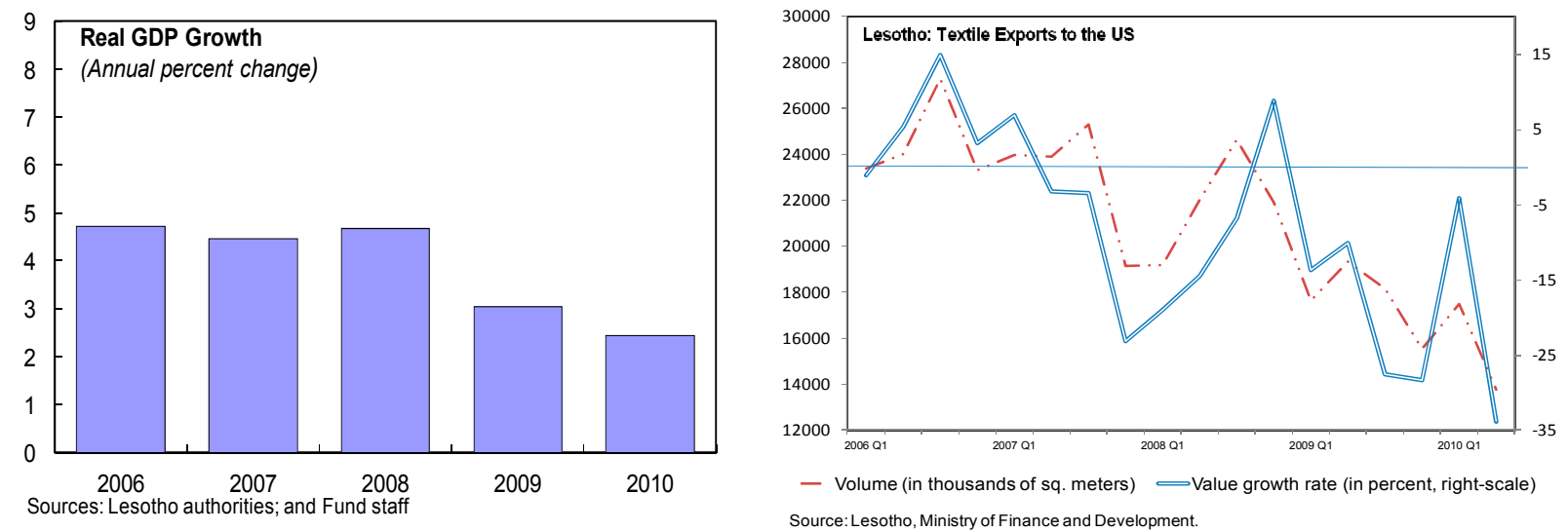

\footnotetext{
${ }^{1}$ SACU revenues have proven to be very volatile. The sharp drop in 2010/11-2011/12 is the result of repayments to the Common Revenue Pool, owing to overpayments for 2008/09 and 2009/10, when South Africa's imports were affected by the global economic crisis.
} 
- The external current account position is estimated to have deteriorated from a broadly balanced position in 2009 to a deficit of some 16 percent of GDP in 2010. The deterioration reflects the fall in SACU revenues and a widening of the trade deficit. International reserves declined, but the drop in U.S. dollar terms was dampened by valuation effects, as reserves are mostly denominated in rand.

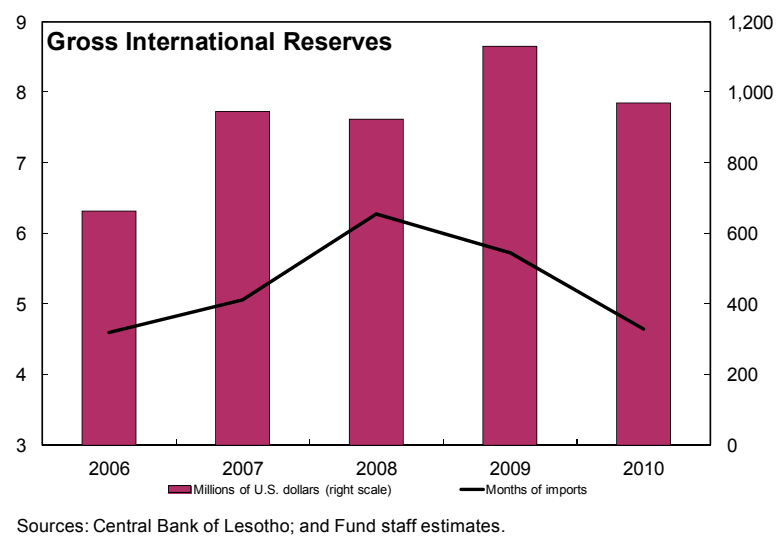

Sources: Central Bank of Lesotho; and Fund staff estimates.

- Inflation fell to 3.8 percent in 2010 , benefiting from the strong loti, as well as lower domestic food price pressures. The expectation is for inflation to rise as a result of the re-emergence of global commodity and fuel price pressures.

\section{Fiscal performance during the first half of 2010/11 was strong, suggesting a} significantly lower full-year deficit than earlier projected. Preliminary data for AprilSeptember ${ }^{2}$ indicate a deficit of 0.2 percent of GDP, compared with a projected deficit of 6.4 percent of GDP under the program. The sharp improvement reflected mainly a boost in revenues from an unexpected SACU receipt and a large dividend payment from the Central Bank of Lesotho (CBL), amounting together to some 6 percent of GDP. ${ }^{3}$ This windfall was partially used to finance a one-off payment to the pension fund, initially planned for 2011/12, with the remainder being saved. ${ }^{4}$ On this basis, and assuming adherence to the existing budget spending ceilings, with a backloaded spending pattern, the fiscal deficit for FY2010/11 is projected at 8.2 percent of GDP, compared with 19.0

\begin{tabular}{|c|c|c|}
\hline \multicolumn{3}{|c|}{ Fiscal Performance April-Sept. FY2010/11 } \\
\hline \multicolumn{3}{|c|}{$\begin{array}{c}\text { Prel } \\
\text { April-Sept. }\end{array}$} \\
\hline Revenue and grants & 28.3 & 24.8 \\
\hline Revenue & 24.8 & 21.0 \\
\hline Tax Revenue & 19.2 & 16.6 \\
\hline $\mathrm{o} / \mathrm{w}$ Customs revenue (SACU) & 9.7 & 6.9 \\
\hline Non-tax revenue & 5.5 & 4.5 \\
\hline Grants & 3.5 & 3.7 \\
\hline Total Expenditure \& net lending & 28.5 & 31.2 \\
\hline Recurrent expenditure & 18.0 & 19.9 \\
\hline Capital expenditure & 10.5 & 11.2 \\
\hline$o / w$ Domestically funded & 6.8 & 5.4 \\
\hline Overall balance (deficit $=-$ ) & -0.2 & -6.4 \\
\hline \multicolumn{3}{|l|}{ Memo Item: } \\
\hline FY nominal GDP (millions of maloti) & 15,910 & 15,780 \\
\hline
\end{tabular}
percent of GDP projected under the program.

\footnotetext{
${ }^{2}$ The fiscal year runs from April to March.

${ }^{3}$ Lesotho received M466.6 million in SACU revenue following a tribunal settlement between South Africa and the BLNS over disputed shares for 2006/07-2007/08. In addition, the CBL paid dividends of M500 million from retained earnings for 2008 and 2009.

${ }^{4}$ The decision to pay a M250 million liability to the pension fund during the current fiscal year came after more detailed analysis of the impact on the fiscal profile of the interest costs on this liability. The payment does not affect the fiscal balance, but is instead recorded as a negative financing item in the fiscal accounts.
} 


\section{Program Performance}

4. The program is on track. All quantitative performance criteria (PCs) for endSeptember 2010 were met, except for the floor on the stock of NIR which was missed by a small margin, reflecting higher-than-projected private sector imports. Reserves have subsequently risen above the end-September target (measured at program exchange rates). The indicative targets for the floor on social spending and the ceiling on payments of domestic arrears were also met (MEFP, Table 1). Regarding the indicative targets for endDecember 2010, all the targets were met, reflecting significantly lower than projected fiscal and external current account deficits.

\section{Implementation of key structural reforms is progressing steadily, albeit with delays in meeting some of the benchmarks (MEFP, Table 2).}

- In the area of public financial management: (a) modifications have been made to the Integrated Financial Management Information System (IFMIS) to prevent over-commitment; (b) the audit of user access rights was completed, albeit with delay; and (c) the submission to Cabinet of a comprehensive review of on-going capital projects was delayed to allow for broader consultations with line ministries; it is now scheduled for end-March 2011.

- Regarding improvements in the business climate, a new Companies Bill was submitted to Parliament in August. Its passage should significantly simplify the burden of starting a business.

- In the financial sector, the authorities successfully placed M125 million of 3year and 5-year treasury bonds in the domestic market. The submission to Parliament of the Financial Institutions Act was delayed by changes in consultants and a tight Parliamentary schedule, but the authorities are committed to submit the new Financial Institutions Bill ${ }^{5}$ to Parliament by endMarch 2011.

\section{Policy Discussions}

6. The authorities reiterated their firm commitment to the policies and objectives outlined in the May 17, 2010 MEFP. These entail:

(i) significant fiscal consolidation, with the bulk of the adjustment coming from reductions in non-productive and non-priority spending, while ensuring adequate resources for growth-enhancing infrastructure projects and protecting spending for vulnerable groups;

\footnotetext{
${ }^{5}$ The new legislation is now referred to as a Bill because it replaces, rather than amends, the earlier Act.
} 
(ii) strengthening the financial sector's regulatory framework while deepening financial intermediation; and

(iii) improving the business climate to boost productivity and external competitiveness and diversify the economy.

These policies, together with the projected increase in SACU revenues, are expected to bring about a gradual improvement in the fiscal balance toward a surplus of about $1 \frac{1 / 4}{4}$ percent of GDP in 2015/16; a return of the external current account to sustainable levels; and a recovery in growth driven by major public infrastructure projects (Figure 1). These include the Metolong Dam project and the second phase of the Lesotho Highlands Water Project (LHWP2) - a large bi-national project with South Africa, focused on water and electricity generation and an anticipated driver of growth and foreign exchange earnings upon completion. ${ }^{6}$ The debt dynamics are projected to remain broadly unchanged - though at a lower level - reflecting a moderate risk of debt distress after incorporating financing assumptions for LHWP2 on commercial terms, consistent with the nature of the project.

Lesotho: Medium-Term Key Economic Indicators, 2010-2015

\begin{tabular}{|c|c|c|c|c|c|c|}
\hline & \multicolumn{5}{|c|}{ Projections } & \multirow[b]{2}{*}{2015} \\
\hline & 2010 & 2011 & 2012 & 2013 & 2014 & \\
\hline & \multicolumn{6}{|c|}{ (Annual percentage change, unless otherwise indicated) } \\
\hline Real GDP Growth & 2.4 & 3.1 & 4.1 & 4.7 & 4.7 & 5.1 \\
\hline \multirow{2}{*}{ Consumer price index (eop) } & 3.1 & 5.6 & 5.7 & 5.7 & 5.7 & 5.6 \\
\hline & \multicolumn{6}{|c|}{ (In percent of GDP, unless otherwise indicated) } \\
\hline Overall fiscal balance $V$ & -8.2 & -15.0 & -5.3 & -2.6 & -0.6 & 1.3 \\
\hline Overall fiscal balance (excl. M etolong) $v$ & -7.3 & -14.2 & -2.7 & -1.0 & 0.7 & 1.3 \\
\hline Non-SACU fiscal balance $3 /$ & -24.7 & -30.2 & -26.7 & -23.0 & -19.5 & -16.5 \\
\hline Government debt $v$ & 37.8 & 41.6 & 45.9 & 46.7 & 45.9 & 44.6 \\
\hline Domestic debt & 3.9 & 5.8 & 6.6 & 6.4 & 6.0 & 5.6 \\
\hline External debt & 33.9 & 35.9 & 39.3 & 40.3 & 39.9 & 39.0 \\
\hline External debt-service ratio $2 /$ & 4.1 & 3.8 & 3.7 & 3.7 & 3.6 & 4.1 \\
\hline Current account balance & -16.1 & -23.4 & -17.8 & -13.1 & -10.5 & -7.0 \\
\hline Gross official reserves (US\$ millions) & 970.3 & 681.9 & 612.0 & 662.2 & 721.2 & 797.9 \\
\hline Months of imports of goods and services & 4.7 & 3.0 & 2.6 & 2.7 & 2.8 & 2.9 \\
\hline $\begin{array}{l}\text { Sources: Lesotho authorities; and IMF staff estima } \\
\text { V Fiscal data are reported on a fiscal year basis; fi } \\
\text { 2/ In percent of exports of goods and services. }\end{array}$ & $\begin{array}{l}\text { jections. } \\
\text { gins in April }\end{array}$ & & & & & \\
\hline
\end{tabular}

\section{With the medium-term outlook broadly unchanged, the policy discussions} focused on the FY2011/12 budget and the authorities' structural reform agenda. Staff and the authorities reached agreement on a broad macroeconomic framework and on quantitative performance criteria and structural benchmarks for 2011/12. Quantitative performance criteria for end-March 2011 were also adjusted in view of the improved fiscal performance.

\footnotetext{
${ }^{6}$ See Box 1, EBS/10/88, May 18, 2010.
} 
Figure 1. Lesotho: Medium-Term Outlook, 2010-15

Growth is expected to recover over the medium term, driven by large infrastructure spending ...

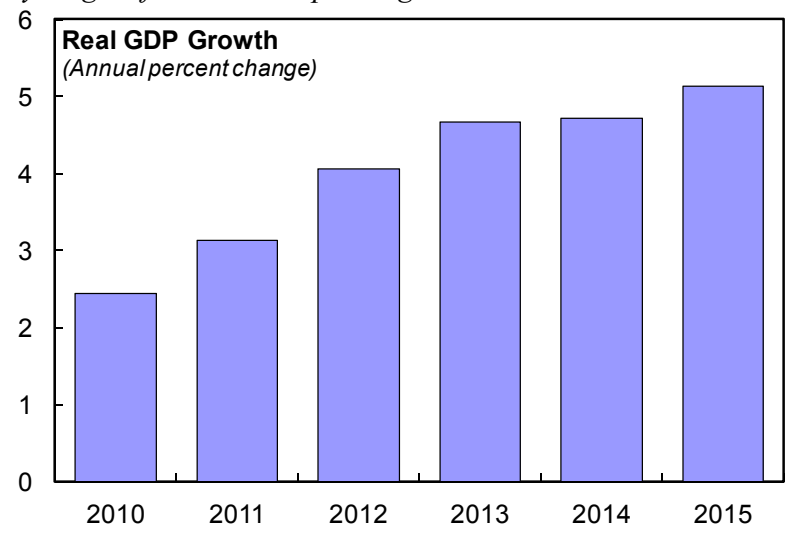

Sources: Lesotho authorities; and Fund staff estimates.

Fiscal consolidation will focus on containing expenditure.

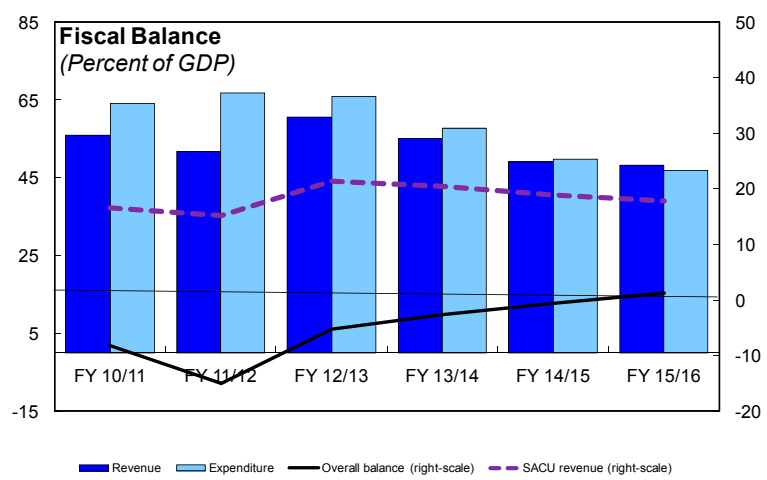

Souces: Ministry of Finance and Development Planning; and Fund staff estimates

... allowing reserves to be rebuilt in the medium term to support the peg....

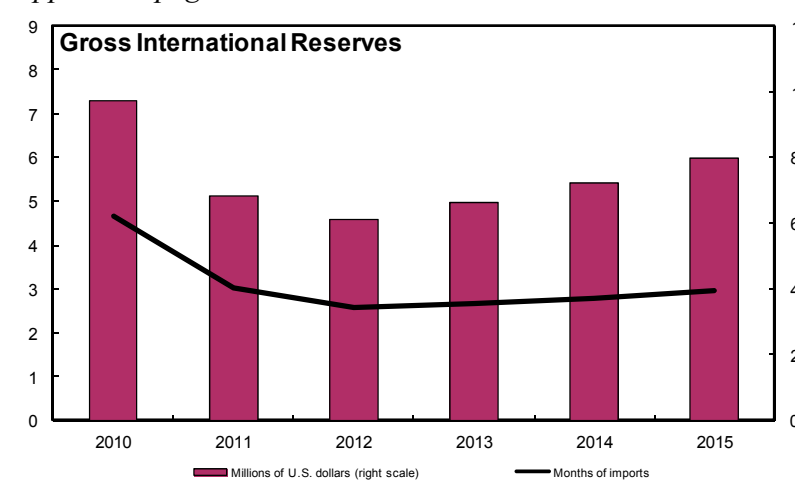

Sources: Central Bank of Lesotho; and Fund staff estimates.
... while inflation is expected to rise somewhat above South Africa's, reflecting a higher responsiveness to food prices.

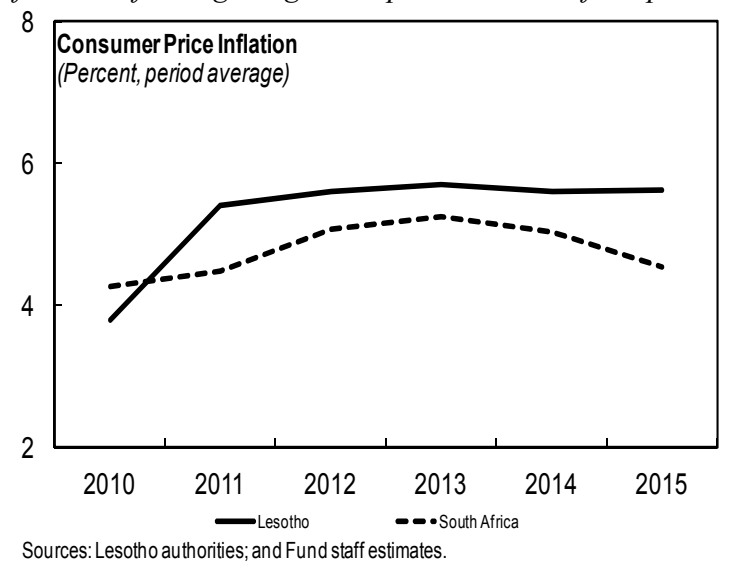

The BOP is expected to improve with fiscal consolidation and a recovery in $S A C U$ revenue....

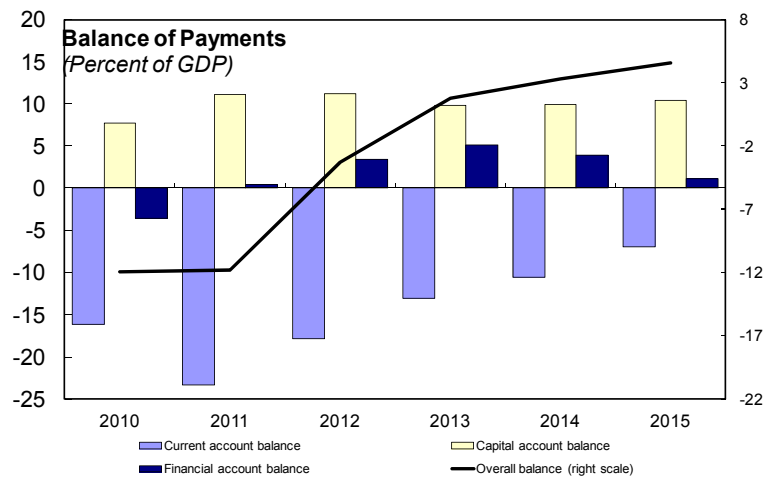

Sources: Central Bank of Lesotho; and Fund staff estimates

...while a stronger loti has reduced the external debt ratio.

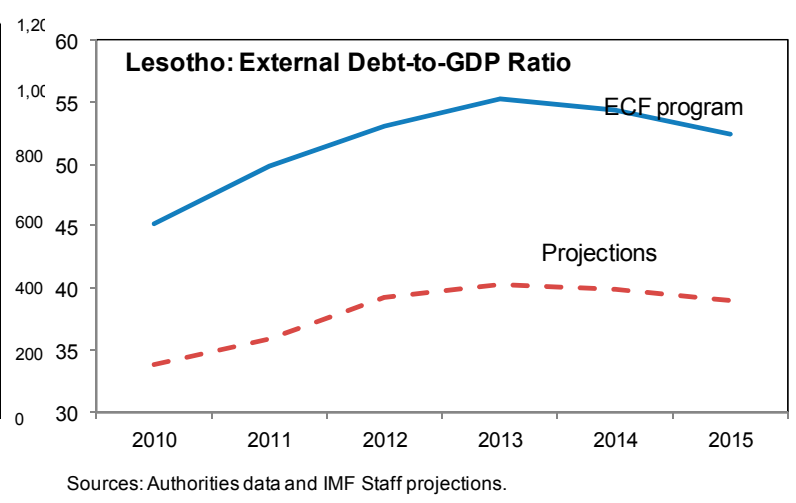


8. Risks to the outlook and the program appear manageable. These arise mainly from a potentially weaker external environment; lower SACU revenues; policy slippages in light of the large fiscal adjustment needs; and delays in implementing structural reforms. The government's commitment to the program, evidenced by its implementation record, thus far, suggests that these risks are contained.

\section{A. Dealing With Fiscal Pressures}

Fiscal policy for 2011/2 will be formulated against the backdrop of lower revenues and additional spending commitments ${ }^{7}$.

\section{Revenues are projected to fall in 2011/12, reflecting the disappearance of} exceptional receipts in 2010/11. Specifically, the fiscal accounts will not benefit from the extraordinary CBL transfer, and SACU receipts are also projected to be lower. Both factors combined will shave off some 4 percent of GDP from the revenue ratio. While current projections do not assume increases in other revenues, the authorities will strive for ongoing improvements in tax administration and compliance, focused on strengthening tax collection, providing better services to taxpayers, and further improving the operational efficiency of the Lesotho Revenue Authority (LRA), with technical assistance from the U.S. Treasury Department and the Fund. The automation of the cashier system at the border stations will also help improve revenue collection.

\section{On the spending side, the authorities are facing a number of additional} commitments - some of which of a temporary nature. These commitments amount together to $4 \frac{3}{4} 4$ percent of GDP and include:

- A significant increase in wages and salaries (1 1 $\frac{1}{4}$ percent of GDP), reflecting the introduction of a new salary scale for teachers, consistent with provisions of the new Education Act, that is intended to stem serious retention problems; new positions in the areas of national security and defense; and an across-the-board salary increase of 5 percent. ${ }^{8}$ To partially offset the impact of these measures, the authorities will freeze all other new positions, while eliminating nonpriority posts vacated for more than a year.

- Higher capital spending (1 1/4 percent of GDP) related to the delayed construction of the Metolong Dam project and the associated carry-over of expenditure originally

\footnotetext{
${ }^{7}$ The FY2011/12 budget was submitted to Parliament on February 14, 2011.

${ }^{8}$ As in many other civil services, public employees also receive notch (step) adjustments, for which the budget provides for an increase of $3 \frac{1}{2}$ percent. In past years, the impact of these adjustments on the wage bill was only around $3 / 4$ percent, suggesting that the budget projections may overstate expected outlays for wages and salaries.
} 
planned for 2010/11. This increase is partially offset by lower domestically-funded capital spending, reflecting the authorities' efforts to improve project prioritization, monitoring, and evaluation, drawing on the recommendations of the Project Appraisal Committee.

- Higher interest payments on domestic debt ( $3 / 4$ percent of GDP), as a result of the recent introduction of treasury bonds - rather than a further drawdown of government deposits at the $\mathrm{CBL}$ - to help finance the fiscal deficit.

- The cost of carrying out local and national government elections, scheduled for February 2012 (1 1 $\frac{1}{2}$ percent of GDP), with a firm commitment to resist indirect election-related spending pressures.

\section{To contain the increase in the deficit, the authorities are committed to a} reduction in other primary spending by 2 percentage points of GDP. To achieve this objective, they will maintain tight limits on appropriations for goods and services and on subsidies. Further improvements in public financial management will also be crucial to achieve the desired savings (Box 1). Finally, spending on key social programs, such as the school feeding program, old age pensions, and HIV/AIDS will be preserved, with the floor maintained at M680 million, equivalent to 3.8 percent of GDP.

\section{Box 1. Improving Public Financial Management}

Further strengthening of public financial management remains key for enhancing the effectiveness of public expenditure and supporting fiscal consolidation. To this end, the authorities are planning to implement a number of important measures (MEFP $\mid 14-16$ ):

- Review of current spending, following a similar review of capital expenditure, to identify low priority outlays that can be eliminated.

- Development of a time-bound plan for capacity building in ministries to strengthen the preparation of medium-term expenditure frameworks.

- Improvements in the functionality of the Integrated Financial Management Information System (IFMIS) to strengthen expenditure controls, improve revenue tracking, and enhance accountability. Activities will focus on resolving interface problems, increasing staff training in the use of the system, and establishing a front office revenue receipting system, to ensure that all revenues are captured.

- Reliable identification and clearance of domestic payments arrears, supported by a full audit by end-June 2011, to determine their size, the development of a time-bound plan for their elimination, and implementation of processes that ensure timely payment in the future. The previous ceiling on accumulation of domestic arrears will be discontinued as an indicative target. 
12. The above policies imply a rise in the fiscal deficit to

15 percent of GDP. While this constitutes a deterioration of $63 / 4$ percentage points of GDP from the expected $2010 / 11$ outturn, the deficit would still be considerably lower than envisaged under the original program.

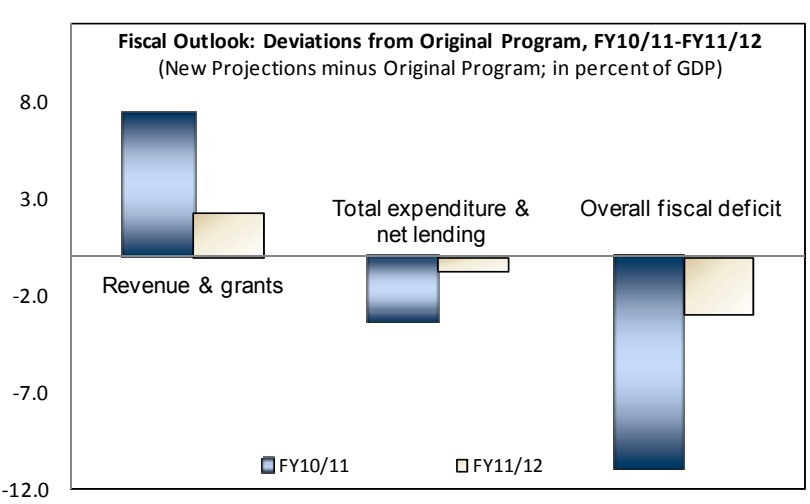

13. The deficit will be financed through a combination of domestic resources and external grants and loans. A drawdown in deposits at the CBL and the issuance of an additional M500 million in domestic bonds will finance most of the fiscal deficit. To preserve debt sustainability, the authorities will continue to seek external financing through grants and concessional loans. As agreed under the program, non-concessional financing will be used only for the Metolong Dam project. In addition, while spending commitments under LHWP2 remain uncertain, and financing is not expected to be contracted in the near term, it is unlikely that it will be available on concessional terms. Thus, provisions for additional nonconcessional financing may need to be considered in the future. In the event that fiscal performance is better than expected, including as a result of higher-than-programmed SACU receipts, the authorities have agreed to use the additional resources to rebuild their deposits at the CBL.

\section{B. Mitigating Financial Sector Risk and Supporting Development}

14. The government is moving ahead with financial sector reforms. While banks' income positions have declined along with the drop in market interest rates around the world, the sector remains well capitalized and profitable.

Vulnerabilities, however, stem from weakly supervised nonbank financial institutions (NBFIs). Reforms are therefore focused on bringing nonbanks into an overall strengthened regulatory and supervisory framework, while also enhancing access to financial services,

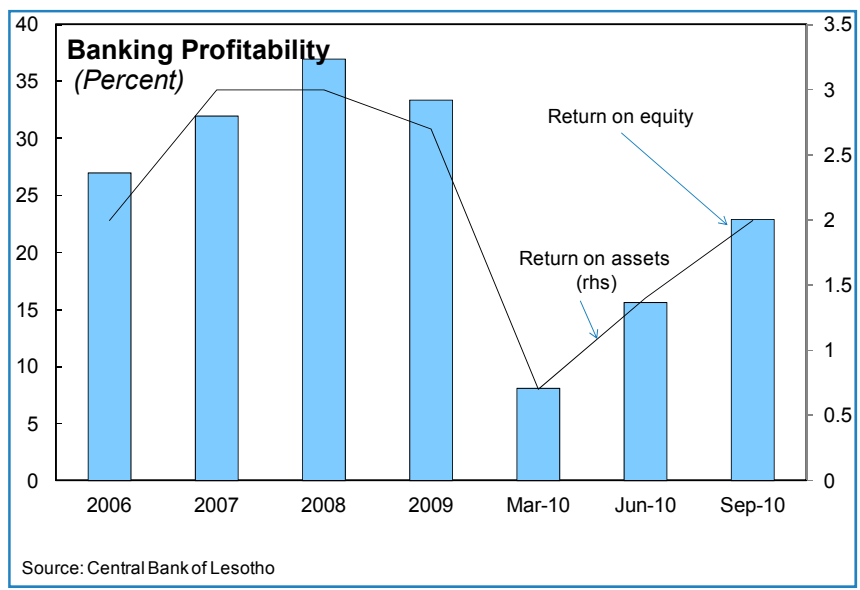
particularly for rural areas. 


\section{Consistent with these objectives, the authorities are committed to the following actions:}

- Submitting to Parliament a new Financial Institutions Bill (structural benchmark), which incorporates amendments to deal with supervision of NBFIs by the CBL, and unlawful business practices, including Ponzi schemes.

- Submitting to Cabinet a review of the Cooperatives Societies Act, with a view to ensuring that cooperatives who accept deposits from the public comply with, and are registered under, the FIA, and are therefore subjected to CBL supervision and the same prudential and anti-money laundering requirements as banks (structural benchmark).

- Completing the draft regulations for the scope and mandate of the Financial Intelligence Unit and the AML regime.

- Advancing the modernization of Postbank, to better enable it to expand its services and products to individuals and small and medium-size enterprises, including those in rural areas. This includes the preparation of a time-bound plan for expansion of microlending products and services, including the introduction of smartcards.

- Launching a Partial Guarantee Scheme and submitting to Cabinet a National Leasing Finance proposal aimed at creating a legal environment conducive to leasing (both structural benchmarks) to enhance access to financial services.

\section{Improving Productivity and the Investment Climate}

16. The authorities are also focusing on improvements to the business climate in support of private sector-led growth and economic diversification. They acknowledge that the difficulties in the textile sector and Lesotho's poor rankings in business climate indicators reinforce the need to fast-track reforms. Building on the progress made to dateincluding the recently amended Land Reform Act, the new Companies Bill, the automation of the Companies Registry, and the implementation of a new business plan for the One Stop Business Facilitation Centre - the authorities plan to continue their close cooperation with development partners to implement reforms to improve the business climate and foster economic diversification. To this end, the submission of the Industrial Licensing Bill to Parliament (structural benchmark) will be another important achievement. 

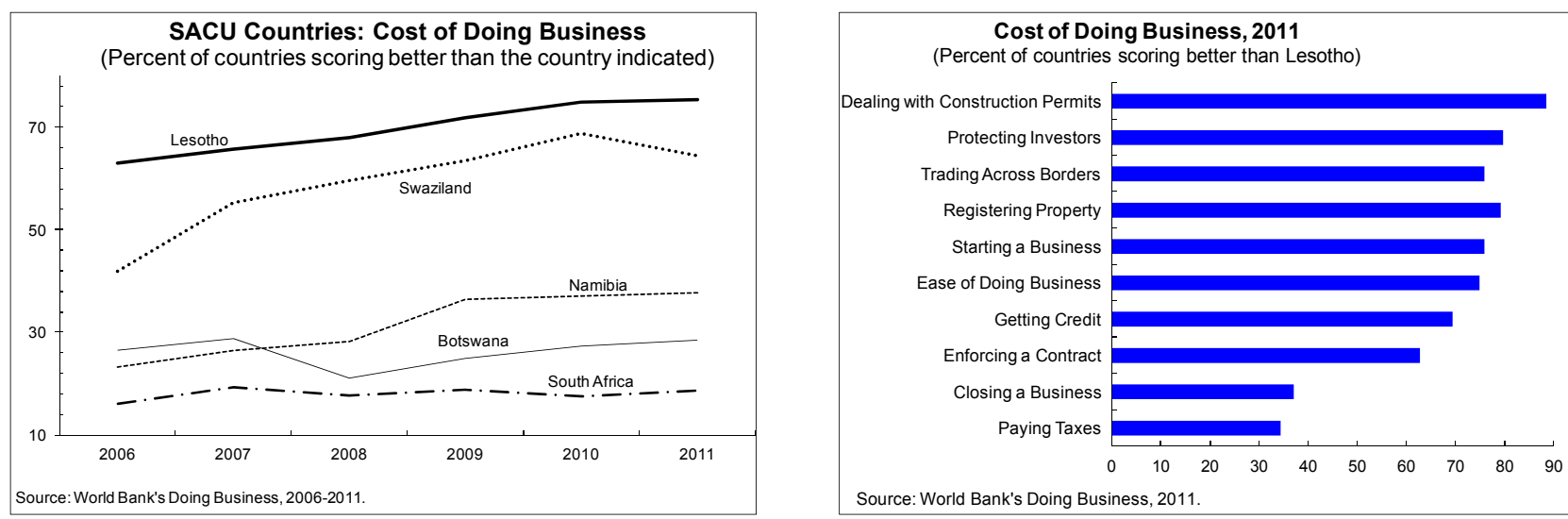

\section{Program Monitoring ANd SAfeguards Assessment}

\section{A. Program Monitoring}

17. The performance criteria (PCs) and benchmarks are proposed to be modified as shown in MEFP, Table 1. The revisions to the net domestic financing and the NDA of the CBL reflect the better-than-programmed projected fiscal performance during the first half of FY2010/11, and the revision to the international reserves reflects actual developments through December and a backloaded fiscal expenditure profile. Completion of the second and third reviews of the arrangement, by August 17, 2011 and February 24, 2012, respectively, will be based on the observance of quantitative performance criteria through end-March 2011 and end-September 2011, respectively (MEFP, Table 1). The targets for end-June 2011 will be indicative. Structural benchmarks have been established through end-September 2011 (MEFP, Table 3). The definitions of the variables monitored as quantitative performance criteria are provided in the Technical Memorandum of Understanding (TMU).

\section{Staff supports the authorities' request for a waiver for non-observance of the} performance criterion for end-September floor on the stock of international reserves, as it was missed by a small margin and the program's macroeconomic objectives have not been jeopardized as a result.

\section{B. Safeguards Assessment}

19. An updated safeguards assessment has concluded that the CBL has strengthened key elements of its safeguards framework since the 2003 assessment. International Financial Reporting Standards have been fully implemented, and the CBL has introduced web-based publication of the audited financial statements. Comprehensive investment guidelines have been formalized and the statutory governance framework has also been strengthened through the adoption of by-laws. Risks exist in the external audit mechanism, 
however, and effective audit and control oversight remains a challenge. Controls over the compilation of monetary program data should also be strengthened. The CBL has commenced on the implementation of key recommendations and has committed to the appointment of an international audit firm as the CBL's sole auditor in the revised MEFP.

\section{Poverty Reduction Strategy}

20. The authorities have launched the process for the preparation of a comprehensive five-year National Strategic Development Plan (NSDP) (2012/132016/17), which is planned for implementation in April 2012. The NSDP will aim to achieve Lesotho's development objectives of strong sustained growth for poverty reduction, a strategy currently being implemented through the Interim National Development Framework (INDF) (2008/09-2010/11). The INDF is based on the priorities and objectives contained in the Poverty Reduction Strategy Paper, 2004-2008. The authorities are aware that a PRS document is needed before the second ECF review.

\section{Staff Appraisal}

21. The authorities have successfully embarked on a process of strong fiscal consolidation, made necessary by a severe drop in SACU revenues. Adherence to tight expenditure ceilings and the laudable decision to save a sizeable revenue windfall in FY2010/11 have helped contain the fiscal deficit at a projected level of about $8 \frac{1}{4}$ percent of GDP_considerably lower than earlier anticipated.

22. Thanks to these efforts, and an improved outlook for SACU revenues, the authorities are now in a stronger position to meet new spending pressures. These arise from a sizeable increase in the wage bill, partly as a result of the new pay scale for teachers, higher capital spending, and the need to cover election outlays. Nevertheless, the mediumterm outlook remains challenging, and further fiscal consolidation will be needed, even with larger SACU revenues.

23. Thus, containing overall public spending will be the key economic policy challenge in FY2011/12. To achieve their fiscal deficit target, in the face of the various spending commitments, the authorities will have to tighten other recurrent expenditure, by some 2 percentage points of GDP. This will require close adherence to tight spending ceilings.

24. Going forward, medium-term sustainability will require further fiscal consolidation, while simultaneously creating space for critical public investment. This calls for a phased reduction in recurrent spending over the medium term. In particular, a return to moderate wage increases, as in 2010/11, and containment of public sector employment will be crucial to reduce the public wage bill as a share of GDP from its current 
high level. In addition, the authorities will need to further strengthen tax administration and compliance, as a way to mobilize non-SACU revenue, and continue their efforts to improve public financial management to restore fiscal and external sustainability over the medium term.

25. The authorities are rightly focusing financial sector reforms on reducing vulnerabilities in the nonbank sector and on deepening financial intermediation. Measures to strengthen the regulatory and supervisory framework for the entire financial sector, starting with the passage of the new Financial Institutions Bill, are important to mitigate financial sector risks. At the same time, the authorities have taken a significant step in developing the money and capital markets through the successful placement of domestic treasury bonds. This, along with reforms to improve access to financial services, especially in rural areas, will go a long way in facilitating financial deepening and supporting development.

26. Accelerating reforms to improve the business climate remains an urgent priority for boosting productivity and competitiveness. The uncertainties in the textile sector reinforce the need for fast-tracking reforms to improve the business climate and support export diversification. Various reforms have already been initiated, and the expected submission and adoption of a new Industrial Licensing Bill will be another important step.

27. The ECF-supported program is on track, and staff supports the authorities' request for a waiver for non-observance of the end-September 2010 performance criterion on the stock of international reserves and the modification of the end-March 2011 performance criteria, and recommends completion of the first review. 
Table 1. Lesotho: Selected Economic and Financial Indicators, 2008-15 1/

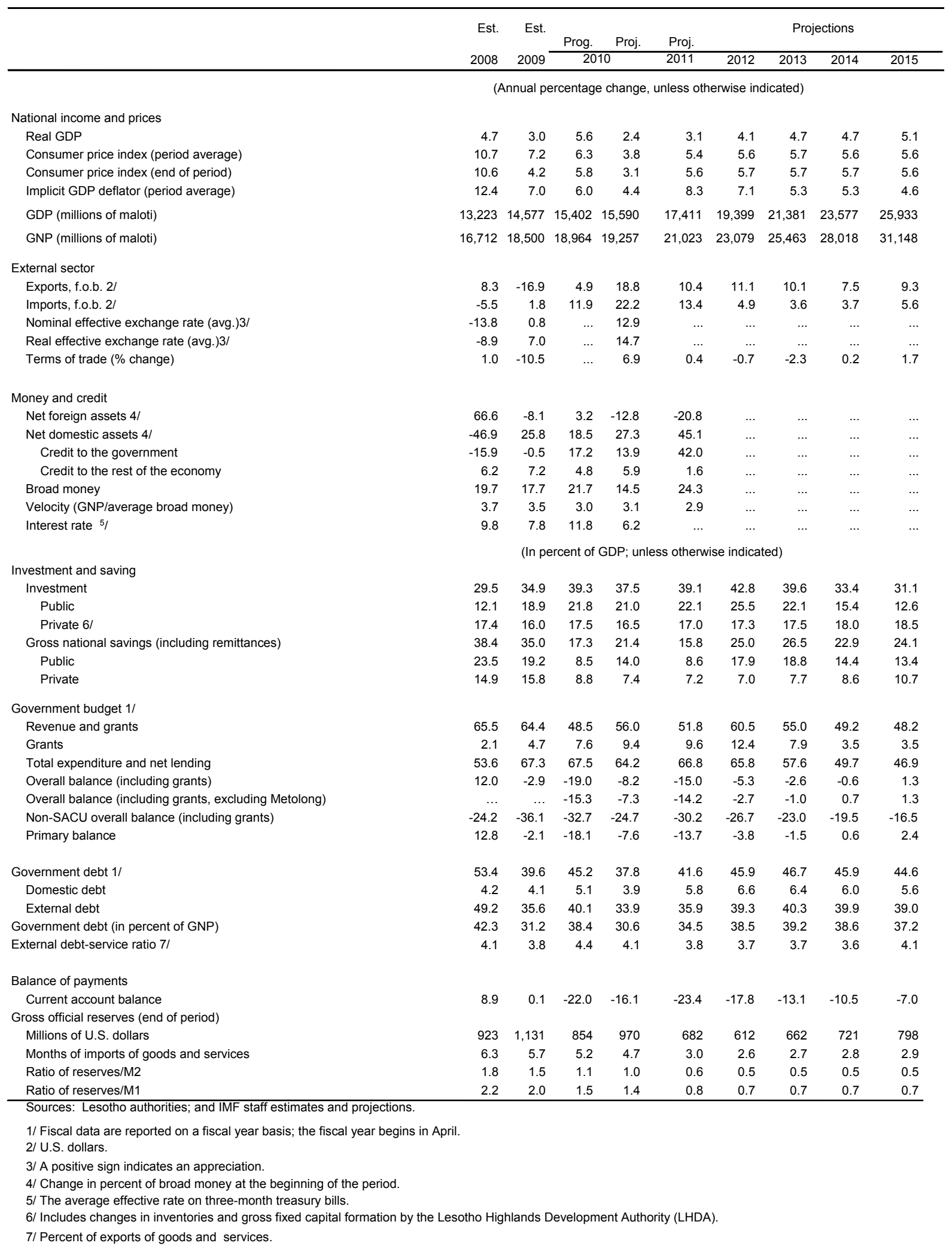


Table 2. Lesotho: Central Government Operations, 2009/10-2015/16 ${ }^{1 /}$

(in millions of maloti)

\begin{tabular}{|c|c|c|c|c|c|c|c|c|}
\hline & \multirow{2}{*}{$\begin{array}{c}\text { Est. } \\
\text { 2009/10 }\end{array}$} & \multirow{2}{*}{$\begin{array}{r}\text { Prog. } \\
2010 / 11\end{array}$} & \multirow{2}{*}{$\begin{array}{c}\text { Proj. } \\
\text { 2010/11 }\end{array}$} & \multirow{2}{*}{$\begin{array}{c}\text { Proj. } \\
2011 / 12\end{array}$} & \multicolumn{4}{|c|}{ Projections } \\
\hline & & & & & $2012 / 13$ & $2013 / 14$ & $2014 / 15$ & $2015 / 16$ \\
\hline Revenue and grants & 9,555 & 7,654 & 8,906 & 9,353 & 12,115 & 12,066 & 11,879 & 12,742 \\
\hline Revenue & 8,861 & 6,458 & 7,408 & 7,624 & 9,635 & 10,344 & 11,034 & 11,817 \\
\hline Tax revenue & 8,170 & 5,549 & 6,097 & 6,705 & 8,636 & 9,249 & 9,828 & 10,433 \\
\hline $\begin{array}{l}\text { Customs revenue (SACU) }{ }^{21} \\
\text { Noncustoms tax revenue }\end{array}$ & $\begin{array}{l}4,918 \\
3,251\end{array}$ & $\begin{array}{l}2,162 \\
3,387\end{array}$ & $\begin{array}{l}2,628 \\
3,469\end{array}$ & $\begin{array}{l}2,753 \\
3,953\end{array}$ & $\begin{array}{l}4,287 \\
4,349\end{array}$ & $\begin{array}{l}4,480 \\
4,769\end{array}$ & $\begin{array}{l}4,574 \\
5,254\end{array}$ & $\begin{array}{l}4,688 \\
5,745\end{array}$ \\
\hline Income taxes & 1,772 & 2,012 & 1,941 & 2,212 & 2,448 & 2,682 & 2,955 & 3,233 \\
\hline Sales tax / value-added tax (VAT) & 1,035 & 1,171 & 1,244 & 1,414 & 1,527 & 1,673 & 1,844 & 2,017 \\
\hline Excise taxes (Petrol lewy) & 243 & 108 & 132 & 150 & 170 & 187 & 206 & 225 \\
\hline Other tax revenues & 201 & 84 & 152 & 177 & 204 & 228 & 249 & 270 \\
\hline Nontax revenue & 692 & 909 & 1,311 & 919 & 999 & 1,094 & 1,206 & 1,384 \\
\hline Water royalties & 337 & 386 & 436 & 463 & 490 & 537 & 592 & 712 \\
\hline Interest received & 7 & 8 & 8 & 9 & 8 & 9 & 10 & 11 \\
\hline Other nontax revenues & 348 & 515 & 867 & 447 & 501 & 549 & 604 & 661 \\
\hline Grants & 693 & 1,195 & 1,498 & 1,730 & 2,480 & 1,722 & 846 & 925 \\
\hline Project Grant & 180 & 620 & 618 & 1,044 & 1,729 & 768 & 846 & 925 \\
\hline Budget Support & 513 & 0 & 401 & 153 & 100 & 0 & 0 & 0 \\
\hline MCC & 513 & 575 & 479 & 533 & 651 & 955 & $\ldots$ & .. \\
\hline Total expenditure and net lending & 9,988 & 10,651 & 10,211 & 12,061 & 13,169 & 12,636 & 12,019 & 12,404 \\
\hline Current expenditure & 6,953 & 6,932 & 6,860 & 8,042 & 7,912 & 8,104 & 8,678 & 9,161 \\
\hline Wages and salaries & 2,525 & 2,686 & 2,571 & 3,154 & 3,267 & 3,450 & 3,644 & 3,849 \\
\hline Interest payments & 119 & 147 & 90 & 241 & 298 & 244 & 274 & 291 \\
\hline External & 62 & 83 & 52 & 74 & 106 & 138 & 163 & 176 \\
\hline Domestic & 57 & 65 & 37 & 167 & 192 & 106 & 111 & 115 \\
\hline Goods and services & 1,807 & 1,767 & 1,724 & 1,865 & 1,882 & 1,959 & 2,104 & 2,221 \\
\hline Transfer, subsidies and pensions & 2,498 & 2,119 & 2,433 & 2,497 & 2,428 & 2,416 & 2,619 & 2,763 \\
\hline Pensions and gratuities & 772 & 682 & 713 & 782 & 810 & 847 & 933 & 1,011 \\
\hline Subventions and transfers & 1,726 & 1,437 & 1,720 & 1,714 & 1,619 & 1,569 & 1,686 & 1,752 \\
\hline Other expenditure & 4 & 214 & 43 & 286 & 36 & 36 & 36 & 36 \\
\hline Capital expenditure & 3,035 & 3,726 & 3,352 & 4,024 & 5,262 & 4,534 & 3,343 & 3,245 \\
\hline Domestically funded & 2,055 & 1,689 & 1,988 & 1,615 & 1,700 & 1,769 & 1,803 & 1,923 \\
\hline Externally funded & 980 & 2,037 & 1,364 & 2,409 & 3,562 & 2,764 & 1,540 & 1,322 \\
\hline Net lending & 0 & -7 & 0 & -5 & -4 & -2 & -2 & -2 \\
\hline Overall balance, incl. grants & -433 & $-2,997$ & $-1,305$ & $-2,708$ & $-1,054$ & -570 & -140 & 338 \\
\hline Overall balance (incl. grants, excl. Metolong) & $\ldots$ & $-2,408$ & $-1,154$ & $-2,567$ & -535 & -222 & 176 & 338 \\
\hline Non-SACU balance 3/ & $-5,351$ & $-5,159$ & $-3,933$ & $-5,460$ & $-5,341$ & $-5,050$ & $-4,714$ & $-4,351$ \\
\hline Primary balance & -314 & $-2,850$ & $-1,216$ & $-2,467$ & -756 & -326 & 134 & 629 \\
\hline Total financing & -10 & 2,997 & 1,226 & 2,708 & 1,054 & 570 & 140 & -338 \\
\hline External financing, net & 32 & 1,320 & 221 & 485 & 998 & 837 & 280 & 273 \\
\hline Loan drawings & 286 & 841 & 267 & 770 & 1,182 & 1,042 & 378 & 397 \\
\hline New commitments & & 718 & 151 & 0 & 114 & 117 & 121 & 122 \\
\hline Amortization & -228 & -239 & -196 & -285 & -298 & -323 & -219 & -246 \\
\hline Domestic financing, net & -42 & 1,677 & 1,005 & 2,223 & 56 & -267 & -141 & -611 \\
\hline Banking Sector & 8 & 1,627 & 1,453 & 2,423 & 56 & -267 & -141 & -611 \\
\hline Monetary authorities & 91 & 1,627 & 1,398 & 1,923 & $\ldots$ & $\ldots$ & $\ldots$ & $\ldots$ \\
\hline Deposit money banks & -82 & 0 & 56 & 500 & $\ldots$ & $\ldots$ & $\ldots$ & $\ldots$ \\
\hline Non-banks & 0 & 250 & 0 & 0 & $\ldots$ & $\ldots$ & $\ldots$ & $\ldots$ \\
\hline Other domestic ${ }^{4 /}$ & -250 & $\ldots$ & -250 & $\ldots$ & $\ldots$ & $\ldots$ & $\ldots$ & $\ldots$ \\
\hline Change in domestic arrears & 200 & -200 & -199 & -200 & $\ldots$ & $\ldots$ & $\ldots$ & $\ldots$ \\
\hline Float ${ }^{5 /}$ & 443 & 0 & 79 & 0 & 0 & 0 & 0 & 0 \\
\hline
\end{tabular}

Sources: Ministry of Finance and Development Planning, and Fund staff estimates and projections.

1/ The fiscal year runs from April 1- March 31.

2/ FY2010/11 includes M466.6 million windfall in SACU revenue receipt.

$3 /$ Overall balance excluding customs revenue (SACU)

4 / Include payments of liabilities to the pension fund for the defined contribution pension scheme

5/ The exceptionally high floats reflect teething problems with the IFMIS that prevented timely payment in 2009/10, which were shifted into 2010/11. 
Table 3. Lesotho: Central Government Operations, 2009/10-2015/16 ${ }^{1 /}$ (in percent of GDP, unless otherwise indicated)

\begin{tabular}{|c|c|c|c|c|c|c|c|c|}
\hline & \multirow{2}{*}{$\begin{array}{c}\text { Est. } \\
\text { 2009/10 }\end{array}$} & \multirow{2}{*}{$\begin{array}{l}\text { Prog. } \\
2010 / 11\end{array}$} & \multirow{2}{*}{$\begin{array}{l}\text { Proj. } \\
\text { 2010/11 }\end{array}$} & \multirow{2}{*}{$\begin{array}{l}\text { Prog. } \\
\text { 2011/12 }\end{array}$} & \multicolumn{4}{|c|}{ Projections } \\
\hline & & & & & $2012 / 13$ & $2013 / 14$ & $2014 / 15$ & $2015 / 16$ \\
\hline Revenue and grants & 64.4 & 48.5 & 56.0 & 51.8 & 60.5 & 55.0 & 49.2 & 48.2 \\
\hline Revenue & 59.8 & 40.9 & 46.6 & 42.2 & 48.1 & 47.2 & 45.7 & 44.7 \\
\hline Customs revenue (SACU) ${ }^{2 l}$ & 33.2 & 13.7 & 16.5 & 15.2 & 21.4 & 20.4 & 18.9 & 17.7 \\
\hline Noncustoms tax revenue & 21.9 & 21.5 & 21.8 & 21.9 & 21.7 & 21.7 & 21.7 & 21.7 \\
\hline Income taxes & 12.0 & 12.8 & 12.2 & 12.2 & 12.2 & 12.2 & 12.2 & 12.2 \\
\hline Sales tax / value-added tax (VAT) & 7.0 & 7.4 & 7.8 & 7.8 & 7.6 & 7.6 & 7.6 & 7.6 \\
\hline Petrol lewy & 1.6 & 0.7 & 0.8 & 0.8 & 0.9 & 0.9 & 0.9 & 0.9 \\
\hline Other tax revenues & 1.4 & 0.5 & 1.0 & 1.0 & 1.0 & 1.0 & 1.0 & 1.0 \\
\hline Nontax revenue & 4.7 & 5.8 & 8.2 & 5.1 & 5.0 & 5.0 & 5.0 & 5.2 \\
\hline Water royalties & 2.3 & 2.4 & 2.7 & 2.6 & 2.4 & 2.4 & 2.4 & 2.7 \\
\hline Interest received & 0.1 & 0.1 & 0.0 & 0.0 & 0.0 & 0.0 & 0.0 & 0.0 \\
\hline Other nontax revenues & 2.3 & 3.3 & 5.5 & 2.5 & 2.5 & 2.5 & 2.5 & 2.5 \\
\hline Grants & 4.7 & 7.6 & 9.4 & 9.6 & 12.4 & 7.9 & 3.5 & 3.5 \\
\hline o/w MCC & 3.5 & 3.6 & 3.0 & 2.9 & 3.3 & 4.4 & $\ldots$ & $\ldots$ \\
\hline Total expenditure and net lending & 67.3 & 67.5 & 64.2 & 66.8 & 65.8 & 57.6 & 49.7 & 46.9 \\
\hline Current expenditure & 46.9 & 43.9 & 43.1 & 44.5 & 39.5 & 37.0 & 35.9 & 34.7 \\
\hline Wages and salaries & 17.0 & 17.0 & 16.2 & 17.5 & 16.3 & 15.7 & 15.1 & 14.6 \\
\hline Interest payments & 0.8 & 0.9 & 0.6 & 1.3 & 1.5 & 1.1 & 1.1 & 1.1 \\
\hline External & 0.4 & 0.5 & 0.3 & 0.4 & 0.5 & 0.6 & 0.7 & 0.7 \\
\hline Domestic & 0.4 & 0.4 & 0.2 & 0.9 & 1.0 & 0.5 & 0.5 & 0.4 \\
\hline Goods and services & 12.2 & 11.2 & 10.8 & 10.3 & 9.4 & 8.9 & 8.7 & 8.4 \\
\hline Transter, subsidies and pensions & 16.8 & 13.4 & 15.3 & 13.8 & 12.1 & 11.0 & 10.8 & 10.5 \\
\hline Pensions and gratuities & 5.2 & 4.3 & 4.5 & 4.3 & 4.0 & 3.9 & 3.9 & 3.8 \\
\hline Subventions and transfers & 11.6 & 9.1 & 10.8 & 9.5 & 8.1 & 7.2 & 7.0 & 6.6 \\
\hline Other expenditure & 0.0 & 1.4 & 0.3 & 1.6 & 0.2 & 0.2 & 0.1 & 0.1 \\
\hline Capital expenditure & 20.5 & 23.6 & 21.1 & 22.3 & 26.3 & 20.7 & 13.8 & 12.3 \\
\hline Domestically funded & 13.9 & 10.7 & 12.5 & 8.9 & 8.5 & 8.1 & 7.5 & 7.3 \\
\hline Externally funded & 6.6 & 12.9 & 8.6 & 13.3 & 17.8 & 12.6 & 6.4 & 5.0 \\
\hline Overall balance, incl. grants & -2.9 & -19.0 & -8.2 & -15.0 & -5.3 & -2.6 & -0.6 & 1.3 \\
\hline Overall balance (incl. grants, excl. Metolong) & $\ldots$ & -15.3 & -7.3 & -14.2 & -2.7 & -1.0 & 0.7 & 1.3 \\
\hline Non-SACU balance $3 /$ & -36.1 & -32.7 & -24.7 & -30.2 & -26.7 & -23.0 & -19.5 & -16.5 \\
\hline Primary balance & -2.1 & -18.1 & -7.6 & -13.7 & -3.8 & -1.5 & 0.6 & 2.4 \\
\hline Total financing & -0.1 & 19.0 & 7.7 & 15.0 & 5.3 & 2.6 & 0.6 & -1.3 \\
\hline External financing (net) & 0.2 & 8.4 & 1.4 & 2.7 & 5.0 & 3.8 & 1.2 & 1.0 \\
\hline Loan drawings & 1.9 & 5.3 & 1.7 & 4.3 & 5.9 & 4.8 & 1.6 & 1.5 \\
\hline New commitments & & 4.6 & 0.9 & 0.0 & 0.6 & 0.5 & 0.5 & 0.5 \\
\hline Amortization & -1.5 & -1.5 & -1.2 & -1.6 & -1.5 & -1.5 & -0.9 & -0.9 \\
\hline Domestic financing (net) & -0.3 & 10.6 & 6.3 & 12.3 & 0.3 & -1.2 & -0.6 & -2.3 \\
\hline Banking sector & 0.1 & 10.3 & 9.1 & 13.4 & 0.3 & -1.2 & -0.6 & -2.3 \\
\hline Non-banks & 0.0 & 1.6 & 0.0 & 0.0 & $\ldots$ & $\ldots$ & $\ldots$ & $\ldots$ \\
\hline Other domestic ${ }^{4 /}$ & -1.7 & $\ldots$ & -1.6 & 0.0 & $\ldots$ & $\ldots$ & $\ldots$ & $\ldots$ \\
\hline Change in domestic arrears & 1.3 & -1.3 & -1.2 & -1.1 & $\cdots$ & $\ldots$ & $\ldots$ & ... \\
\hline Float $^{5 /}$ & 3.0 & 0.0 & 0.5 & 0.0 & 0.0 & 0.0 & 0.0 & 0.0 \\
\hline \multicolumn{9}{|l|}{ Memorandum items: } \\
\hline GNP at current prices (Millions of maloti) 6/ & 18,500 & 18,964 & 19,257 & 21,023 & 25,462 & 28,010 & 31,149 & 34,072 \\
\hline GDP at current prices (Millions of maloti) 6/ & 14,830 & 15,780 & 15,910 & 18,067 & 20,015 & 21,930 & 24,166 & 26,434 \\
\hline
\end{tabular}

Sources: Ministry of Finance and Development Planning, and Fund staff estimates and projections. 1/ The fiscal year runs from April 1- March 31.

2/ FY2010/11 includes M466.6 million windfall in SACU revenue receipt.

$3 /$ Overall balance excluding customs revenue (SACU)

4/ Include payments of liabilities to the pension fund for the defined contribution pension scheme

5/ The exceptionally high floats reflect teething problems with the IFMIS that prevented timely payment in 2009/10, which were shifted into $2010 / 11$.

$6 /$ On a fiscal year basis. 
Table 4. Lesotho: Balance of Payments, 2008-15

\begin{tabular}{|c|c|c|c|c|c|c|c|c|c|}
\hline & \multirow[b]{2}{*}{2008} & \multirow{2}{*}{$\begin{array}{c}\text { Est. } \\
2009\end{array}$} & \multirow{2}{*}{$\begin{array}{l}\text { Prog. } \\
2010\end{array}$} & \multirow{2}{*}{$\begin{array}{l}\text { Proj. } \\
2010\end{array}$} & \multicolumn{5}{|c|}{ Projections } \\
\hline & & & & & 2011 & 2012 & 2013 & 2014 & 2015 \\
\hline & \multicolumn{9}{|c|}{ (In millions of U.S. dollars) } \\
\hline Trade balance & -643.0 & -817.8 & $-1,079.7$ & $-1,024.5$ & $-1,187.8$ & $-1,186.4$ & $-1,161.6$ & $-1,160.5$ & $-1,179.4$ \\
\hline Exports, f.o.b. & 871.1 & 724.2 & 775.0 & 860.3 & 950.0 & $1,055.8$ & $1,162.3$ & $1,249.1$ & $1,364.9$ \\
\hline Of which: garments & 457.6 & 390.0 & 346.2 & 374.5 & 384.5 & 398.1 & 412.1 & 441.6 & 482.3 \\
\hline Imports f.o.b & $-1,514.1$ & $-1,542.0$ & $-1,854.8$ & $-1,884.8$ & $-2,137.8$ & $-2,242.2$ & $-2,323.9$ & $-2,409.6$ & $-2,544.3$ \\
\hline Of which: garment inputs & -220.7 & -188.1 & -167.0 & -180.6 & -185.4 & -192.0 & -198.7 & -213.0 & -232.6 \\
\hline Services (net) & -323.2 & -360.1 & -41.0 & -458.8 & -523.9 & -549.1 & -574.5 & -617.6 & -687.2 \\
\hline Receipts & 38.8 & 37.5 & 78.5 & 42.6 & 47.1 & 48.7 & 51.4 & 65.3 & 69.1 \\
\hline Of which: water royalties & 0.0 & 0.0 & 22.1 & 0.0 & 0.0 & 0.0 & 0.0 & 0.0 & 0.0 \\
\hline Payments & -362.0 & -397.6 & -119.6 & -501.4 & -571.0 & -597.8 & -626.0 & -682.9 & -756.3 \\
\hline Income (net) & 422.3 & 463.0 & 416.2 & 500.2 & 500.2 & 484.2 & 521.4 & 550.7 & 643.1 \\
\hline Labor income (net) & 583.1 & 608.6 & 366.8 & 755.5 & 835.3 & 890.7 & 959.2 & $1,019.5$ & $1,104.5$ \\
\hline Receipts & 583.1 & 608.6 & 381.1 & 755.5 & 835.3 & 890.7 & 959.2 & $1,019.5$ & $1,104.5$ \\
\hline Of which: miners' wages & 512.7 & 533.0 & 325.3 & 657.7 & 722.4 & 768.0 & 822.7 & 881.8 & 966.2 \\
\hline Payments & 0.0 & 0.0 & -14.2 & 0.0 & 0.0 & 0.0 & 0.0 & 0.0 & 0.0 \\
\hline Investment income (net) & -233.2 & -207.0 & 49.3 & -289.9 & -358.2 & -429.7 & -461.3 & -491.6 & -484.2 \\
\hline Receipts & 104.6 & 93.7 & 75.5 & 76.9 & 66.3 & 62.2 & 67.9 & 56.5 & 64.7 \\
\hline Payments & -337.8 & -300.7 & -26.2 & -366.9 & -424.5 & -491.9 & -529.2 & -548.1 & -548.8 \\
\hline Of which: interest on debt & 0.0 & 0.0 & -9.1 & -7.6 & -12.2 & -12.9 & -16.6 & -21.3 & -25.0 \\
\hline Other & 72.4 & 61.3 & 0.0 & 34.7 & 23.1 & 23.1 & 23.6 & 22.9 & 22.8 \\
\hline Unrequited transfers & 686.1 & 716.7 & 308.4 & 640.3 & 647.4 & 796.0 & 857.9 & 920.3 & $1,000.1$ \\
\hline Official & 564.9 & 584.8 & 306.7 & 478.9 & 473.9 & 621.8 & 665.1 & 703.9 & 763.4 \\
\hline SACU nonduty receipts & 550.6 & 569.7 & 289.3 & 433.7 & 376.9 & 513.6 & 566.1 & 606.1 & 662.9 \\
\hline Rand compensation & 12.0 & 13.4 & 13.2 & 16.4 & 17.0 & 18.0 & 19.4 & 19.9 & 20.9 \\
\hline Other & 2.4 & 1.6 & 4.1 & 28.8 & 79.9 & 90.1 & 79.6 & 77.9 & 79.6 \\
\hline Private & 121.1 & 132.0 & 1.7 & 161.4 & 173.5 & 174.2 & 192.7 & 216.4 & 236.7 \\
\hline Current account (including official transfers) & 142.1 & 1.9 & -396.3 & -342.8 & -564.2 & -455.3 & -356.8 & -307.1 & -223.3 \\
\hline Capital and financial account & -69.8 & 14.8 & 206.2 & 88.4 & 269.9 & 398.2 & 406.8 & 381.4 & 319.2 \\
\hline Capital account (transfers received) & 18.0 & 69.9 & 123.0 & 163.6 & 267.8 & 285.2 & 267.5 & 290.5 & 332.7 \\
\hline Financial account & -87.9 & -55.1 & 83.2 & -75.1 & 2.2 & 113.0 & 139.4 & 90.9 & -13.5 \\
\hline Direct investment & 110.4 & 101.6 & 64.4 & 133.0 & 137.5 & 190.5 & 200.6 & 171.3 & 160.2 \\
\hline Other investment & -198.3 & -156.6 & 18.8 & -208.2 & -135.3 & -77.5 & -61.2 & -80.4 & -173.8 \\
\hline Assets & -230.3 & -182.8 & -146.6 & -242.3 & -231.1 & -223.0 & -198.8 & -207.1 & -234.1 \\
\hline Liabilities & 32.0 & 26.1 & 165.4 & 34.1 & 95.8 & 145.5 & 137.6 & 126.7 & 60.3 \\
\hline Financing & -153.8 & -61.0 & 190.1 & 214.5 & 294.2 & 57.1 & -50.0 & -74.3 & -95.8 \\
\hline o/w Fund credit & & & 12.0 & 12.1 & 17.6 & 17.5 & 17.5 & 0.0 & 0.0 \\
\hline Errors and omissions & 82 & 44 & 0 & 40 & 0 & 0 & 0 & 0 & 0 \\
\hline Memorandum items: & & & (Percen & of GDP, $u$ & nless other & wise indica & ed) & & \\
\hline Trade balance & -40.2 & -47.5 & -60.0 & -48.2 & -49.3 & -46.5 & -42.5 & -39.7 & -36.9 \\
\hline Net remittances (incl. net labor income from abroad) & 44.0 & 43.1 & 20.4 & 43.1 & 41.8 & 41.7 & 42.2 & 42.3 & 41.9 \\
\hline Current account & 8.9 & 0.1 & -22.0 & -16.1 & -23.4 & -17.8 & -13.1 & -10.5 & -7.0 \\
\hline Total SACU receipts (Millions of U.S dollars) & 568.9 & 579.9 & 333.0 & 436.6 & 376.9 & 513.6 & 566.2 & 564.4 & 574.7 \\
\hline Gross official reserves (Millions of U.S. dollars) & 923.1 & $1,131.0$ & 854.5 & 970.3 & 681.9 & 612.0 & 662.2 & 721.2 & 797.9 \\
\hline Months of imports of goods and services $1 /$ & 6.3 & 5.7 & 5.2 & 4.7 & 3.0 & 2.6 & 2.7 & 2.8 & 2.9 \\
\hline Nominal GDP (USD millions) & 1,601 & 1,720 & 1,799 & 2,127 & 2,412 & 2,553 & 2,731 & 2,924 & 3,198 \\
\hline
\end{tabular}

Sources: Central Bank of Lesotho; and IMF staff estimates and projections.

1/ Based on current year imports of goods and services 
Table 5. Lesotho: Monetary Survey, 2008-11

\begin{tabular}{|c|c|c|c|c|c|c|c|c|c|c|c|}
\hline & \multirow{3}{*}{$\begin{array}{r}\text { Dec. } \\
2008\end{array}$} & \multirow{3}{*}{$\begin{array}{l}\text { Dec. } \\
2009\end{array}$} & \multicolumn{5}{|c|}{2010} & \multicolumn{4}{|c|}{2011} \\
\hline & & & \multicolumn{2}{|c|}{ March } & \multicolumn{2}{|c|}{ Sept. } & \multirow{2}{*}{$\begin{array}{l}\text { Dec. } \\
\text { Prel. }\end{array}$} & \multirow{2}{*}{$\begin{array}{r}\text { March } \\
\text { Proj. }\end{array}$} & \multirow{2}{*}{$\begin{array}{c}\text { June } \\
\text { Proj. }\end{array}$} & \multirow{2}{*}{$\begin{array}{c}\text { Sept. } \\
\text { Proj. }\end{array}$} & \multirow{2}{*}{$\begin{array}{l}\text { Dec. } \\
\text { Proj. }\end{array}$} \\
\hline & & & Prog. & Act. & Prog. & Act. & & & & & \\
\hline \multicolumn{12}{|c|}{ (In millions of maloti; unless otherwise indicated) } \\
\hline Net foreign assets & 11,238 & 10,840 & 11,044 & 10,937 & 10,586 & 10,140 & 10,104 & 9,489 & 8,453 & 8,052 & 8,733 \\
\hline Central bank & 8,260 & 7,788 & 7,677 & 7,591 & 6,592 & 6,203 & 6,246 & 5,529 & 4,699 & 4,275 & 4,122 \\
\hline Commercial banks & 2,977 & 3,053 & 3,366 & 3,346 & 3,994 & 3,938 & 3,858 & 3,961 & 3,755 & 3,777 & 4,612 \\
\hline Net domestic assets & $-6,354$ & $-5,094$ & $-4,352$ & $-4,811$ & $-3,874$ & $-3,541$ & $-3,526$ & $-2,611$ & $-1,381$ & -784 & -559 \\
\hline Domestic credit (net) & $-2,466$ & $-2,136$ & $-2,111$ & $-1,775$ & $-2,336$ & -748 & $-1,001$ & 39 & 932 & 1,566 & 1,868 \\
\hline Claims on central government (net) & $-3,973$ & $-3,996$ & $-3,900$ & $-3,638$ & $-4,354$ & $-3,017$ & $-3,198$ & $-2,184$ & $-1,362$ & -749 & -434 \\
\hline Central bank & $-4,233$ & $-4,353$ & $-4,247$ & $-4,024$ & $-4,701$ & $-3,515$ & $-3,640$ & $-2,626$ & $-2,050$ & $-1,562$ & $-1,377$ \\
\hline Commercial banks & 260 & 357 & 347 & 387 & 347 & 497 & 442 & 442 & 688 & 813 & 942 \\
\hline Claims on the rest of the economy & 1,507 & 1,860 & 1,789 & 1,863 & 2,018 & 2,269 & 2,197 & 2,223 & 2,294 & 2,315 & 2,302 \\
\hline Other items (net) & $-3,888$ & $-2,957$ & $-2,241$ & $-3,036$ & $-1,538$ & $-2,793$ & $-2,526$ & $-2,649$ & $-2,312$ & $-2,350$ & $-2,426$ \\
\hline Money and quasi-money (M2) & 4,884 & 5,747 & 6,692 & 6,126 & 6,692 & 6,599 & 6,578 & 6,878 & 7,073 & 7,268 & 8,174 \\
\hline Money & 3,877 & 4,179 & 5,362 & 4,606 & 5,067 & 4,919 & 4,989 & 5,216 & 5,373 & 5,503 & 6,200 \\
\hline \multicolumn{12}{|l|}{ Of which: } \\
\hline Currency outside dep. mon. banks & 402 & 487 & 440 & 499 & 489 & 534 & 539 & 547 & 609 & 595 & 595 \\
\hline Demand deposits & 3,475 & 3,692 & 4,922 & 4,107 & 4,578 & 4,385 & 4,450 & 4,669 & 4,764 & 4,908 & 5,605 \\
\hline Quasi-money & 1,006 & 1,568 & 1,330 & 1,520 & 1,625 & 1,680 & 1,589 & 1,661 & 1,700 & 1,765 & 1,974 \\
\hline \multicolumn{12}{|l|}{ Of which: } \\
\hline Time and savings deposits & 1,006 & 1,568 & 1,330 & 1,520 & 1,625 & 1,680 & 1,589 & 1,661 & 1,700 & 1,765 & 1,974 \\
\hline \multicolumn{12}{|c|}{ (Annual change in percent of beginning of period M2) } \\
\hline Net foreign assets & 66.6 & -8.1 & 3.5 & 1.7 & -4.4 & -12.2 & -12.8 & -9.4 & -25.1 & -31.2 & -20.8 \\
\hline Central bank & 48.3 & -9.7 & -1.9 & -3.4 & -20.8 & -27.6 & -26.8 & -10.9 & -23.5 & -30.0 & -32.3 \\
\hline Commercial banks & 18.3 & 1.5 & 5.5 & 5.1 & 16.4 & 15.4 & 14.0 & 1.6 & -1.6 & -1.2 & 11.5 \\
\hline Net domestic assets & -46.9 & 25.8 & 12.9 & 4.9 & 21.2 & 27.0 & 27.3 & 13.9 & 32.6 & 41.7 & 45.1 \\
\hline Claims on central government (net) & -15.9 & -0.5 & 1.7 & 6.2 & -6.2 & 17.0 & 13.9 & 15.4 & 27.9 & 37.2 & 42.0 \\
\hline Claims on the rest of the economy & 6.2 & 7.2 & -1.2 & 0.1 & 2.8 & 7.1 & 5.9 & 0.4 & 1.5 & 1.8 & 1.6 \\
\hline Claims on the rest of the econ. (yearly change & 20.2 & 23.4 & -3.8 & 0.2 & 8.5 & 22.0 & 18.1 & 1.2 & 4.4 & 5.4 & 4.8 \\
\hline Other items (net) & -37.3 & 19.1 & 12.5 & -1.4 & 24.7 & 2.9 & 7.5 & -1.9 & 3.2 & 2.7 & 1.5 \\
\hline Money and quasi-money (M2) & 19.7 & 17.7 & 16.4 & 6.6 & 16.4 & 14.8 & 14.5 & 4.6 & 7.5 & 10.5 & 24.3 \\
\hline
\end{tabular}

Sources: Central Bank of Lesotho; and IMF staff estimates and projections. 
Table 6. Lesotho: Schedule of ECF Disbursements and Reviews, 2011-13

\begin{tabular}{|c|c|c|}
\hline Date & $\begin{array}{l}\text { Disbursements }{ }^{1} \\
\text { (Millions of SDR) }\end{array}$ & Conditions \\
\hline 9-Jun-10 & 7.80 & Executive Board approval \\
\hline 1-Apr-11 & 5.68 & $\begin{array}{l}\text { Completion of first review, based on observance of } \\
\text { performance criteria through September } 30,2010\end{array}$ \\
\hline 24-Aug-11 & 5.68 & $\begin{array}{l}\text { Completion of second review, based on observance } \\
\text { of performance criteria through March 31, } 2011\end{array}$ \\
\hline 24-Feb-12 & 5.68 & $\begin{array}{l}\text { Completion of third review, based on observance of } \\
\text { performance criteria through September } 30,2011\end{array}$ \\
\hline 20-Aug-12 & 5.68 & $\begin{array}{l}\text { Completion of fourth review, based on observance of } \\
\text { performance criteria through March } 31,2012\end{array}$ \\
\hline $20-F e b-13$ & 5.68 & $\begin{array}{l}\text { Completion of fifth review, based on observance of } \\
\text { performance criteria through September 30, } 2012\end{array}$ \\
\hline 20-May-13 & 5.68 & $\begin{array}{l}\text { Completion of sixth review, based on observance of } \\
\text { performance criteria through March } 31,2013\end{array}$ \\
\hline Total & 41.88 & \\
\hline
\end{tabular}

Source: IMF Staff estimates.

${ }^{1}$ Based on access of 120 percent of quota (SDR 41.88 million), disbursements are expected to take place shortly after the date of the Board meeting. 
Table 7. Lesotho: Indicators of Capacity to Repay the Fund ${ }^{1}$

\begin{tabular}{|c|c|c|c|c|c|c|c|c|c|c|c|}
\hline & \multicolumn{11}{|c|}{ Projections } \\
\hline & 2011 & 2012 & 2013 & 2014 & 2015 & 2016 & 2017 & 2018 & 2019 & 2020 & 2021 \\
\hline \multicolumn{12}{|l|}{$\begin{array}{l}\text { Fund obligations based on existing credit } \\
\text { (in millions of SDRs) }\end{array}$} \\
\hline Principal & 3.9 & 3.2 & 1.8 & 1.1 & 0.8 & 1.6 & 1.6 & 1.6 & 1.6 & 0.8 & 0.0 \\
\hline Charges and interest & 0.0 & 0.0 & 0.0 & 0.0 & 0.0 & 0.0 & 0.0 & 0.0 & 0.0 & 0.0 & 0.0 \\
\hline \multicolumn{12}{|l|}{$\begin{array}{l}\text { Fund obligations based on existing and prospective credit } \\
\text { (in millions of SDRs) }\end{array}$} \\
\hline Principal & 3.9 & 3.2 & 1.8 & 1.1 & 0.8 & 2.1 & 4.4 & 7.2 & 8.4 & 7.6 & 6.3 \\
\hline Charges and interest & 0.0 & 0.2 & 0.3 & 0.3 & 0.3 & 0.3 & 0.3 & 0.2 & 0.2 & 0.1 & 0.1 \\
\hline \multicolumn{12}{|l|}{ Total obligations based on existing and prospective credit } \\
\hline In millions of SDRs & 3.9 & 3.4 & 2.1 & 1.4 & 1.1 & 2.4 & 4.7 & 7.5 & 8.6 & 7.7 & 6.3 \\
\hline In millions of US\$ & 5.8 & 5.1 & 3.1 & 2.1 & 1.7 & 3.8 & 7.2 & 11.4 & 13.1 & 11.8 & 9.6 \\
\hline In percent of exports of goods and services & 0.6 & 0.5 & 0.3 & 0.2 & 0.1 & 0.3 & 0.5 & 0.7 & 0.7 & 0.6 & 0.5 \\
\hline In percent of debt service ${ }^{2}$ & 16.5 & 14.5 & 8.6 & 5.4 & 4.0 & 9.9 & 17.1 & 25.0 & 25.7 & 21.0 & 15.6 \\
\hline In percent of GDP & 0.2 & 0.2 & 0.1 & 0.1 & 0.1 & 0.1 & 0.2 & 0.3 & 0.3 & 0.3 & 0.2 \\
\hline In percent of Gross International Reserves & 0.8 & 0.9 & 0.5 & 0.3 & 0.2 & 0.4 & 0.6 & 0.9 & 0.9 & 0.8 & 0.6 \\
\hline In percent of quota & 11.0 & 9.7 & 5.9 & 3.9 & 3.2 & 7.0 & 13.4 & 21.4 & 24.5 & 22.1 & 18.1 \\
\hline \multicolumn{12}{|l|}{ Outstanding Fund credit } \\
\hline In millions of SDRs & 25.1 & 33.3 & 42.9 & 41.9 & 41.1 & 39.0 & 34.6 & 27.3 & 19.0 & 11.4 & 5.1 \\
\hline In millions of US\$ & 37.9 & 50.0 & 64.7 & 63.8 & 63.3 & 59.8 & 52.9 & 41.7 & 28.9 & 17.6 & 8.0 \\
\hline In percent of exports of goods and services & 3.8 & 4.5 & 5.3 & 4.9 & 4.4 & 4.0 & 3.4 & 2.5 & 1.6 & 0.9 & 0.4 \\
\hline In percent of debt service ${ }^{2}$ & 106.5 & 142.6 & 178.2 & 166.9 & 150.5 & 157.5 & 126.4 & 91.6 & 57.0 & 31.4 & 12.9 \\
\hline In percent of GDP & 1.6 & 2.0 & 2.4 & 2.2 & 2.0 & 1.8 & 1.5 & 1.1 & 0.7 & 0.4 & 0.2 \\
\hline In percent of Gross International Reserves & 5.5 & 8.4 & 10.0 & 8.8 & 7.4 & 6.2 & 4.7 & 3.3 & 2.1 & 1.1 & 0.5 \\
\hline In percent of quota & 71.9 & 95.5 & 123.0 & 120.0 & 117.8 & 111.7 & 99.1 & 78.3 & 54.3 & 32.6 & 14.6 \\
\hline Net use of Fund credit (in millions of SDRs) & 7.5 & 8.2 & 9.6 & -1.1 & -0.8 & -2.1 & -4.4 & -7.2 & -8.4 & -7.6 & -6.3 \\
\hline Disbursements & 11.4 & 11.4 & 11.4 & 0.0 & 0.0 & 0.0 & 0.0 & 0.0 & 0.0 & 0.0 & 0.0 \\
\hline Repayments & 3.9 & 3.2 & 1.8 & 1.1 & 0.8 & 2.1 & 4.4 & 7.2 & 8.4 & 7.6 & 6.3 \\
\hline \multicolumn{12}{|l|}{ Memorandum items: } \\
\hline Exports of goods and services (in millions of US\$) & 997.0 & $1,104.5$ & $1,213.7$ & $1,314.4$ & $1,434.0$ & $1,495.5$ & $1,561.6$ & $1,642.9$ & $1,773.0$ & $1,866.9$ & $1,966.7$ \\
\hline Debt service (in millions of US $\$)^{2}$ & 36 & 35 & 36 & 38 & 42 & 38 & 42 & 46 & 51 & 56 & 62 \\
\hline Nominal GDP (in millions of US\$) & 2,412 & 2,553 & 2,731 & 2,924 & 3,198 & 3,358 & 3,526 & 3,702 & 3,888 & 4,082 & 4,286 \\
\hline Gross International Reserves (in millions of US\$) & 691 & 594 & 644 & 728 & 854 & 972 & 1,115 & 1,259 & 1,402 & 1,546 & 1,689 \\
\hline Quota (millions of SDRs) & 34.9 & 34.9 & 34.9 & 34.9 & 34.9 & 34.9 & 34.9 & 34.9 & 34.9 & 34.9 & 34.9 \\
\hline
\end{tabular}

Sources: IMF staff estimates and projections

${ }^{1}$ ECF disbursements of SDR 7.78 million (22.3 percent of quota) June 9, 2010; six sucessive disbursements of SDR 5.68 million (16.3 percent of quota) upon completion of each of the six reviews, through May 2013; ; in total SDR 41.88 million (120 percent of quota) during 2010-13.

${ }^{2}$ Total debt service includes IMF repayments. 


\section{Attachment I: Kingdom of Lesotho: Supplemental Letter of Intent}

February 24, 2011

Mr. Dominique Strauss-Kahn

Managing Director

International Monetary Fund

Washington, D.C. 20431

United States of America

Dear Mr. Strauss-Kahn:

This letter and the attached Memorandum of Economic and Financial Policies (MEFP), updates and supplements my communication of May 17, 2010; describes performance under the government's economic program and outline our economic policies and program for 2011/12.

The implementation of our economic program, supported by a three-year Extended Credit Facility (ECF) arrangement, is on track. All performance criteria through end-September 2010 have been met, except for the Net International Reserves (NIR) floor which was missed by a small margin. With respect to the structural benchmarks, (a) the Financial Institutions Act was not finalized due to Parliament schedule; (b) the Capital Projects Review was not completed due to administrative constraints and the crowded Cabinet calendar. The Financial Institutions Act (FIA) has been submitted to Parliament and Cabinet is looking at the Government's project portfolio, based on contribution to economic growth, employment, revenue mobilization. In view of the foregoing, the Government of Lesotho wishes to seek a waiver for inability to meet the performance criterion on NIR and requests completion of the first review, modification of the end-March 2011 performance criteria and disbursement of the second tranche under the program, equivalent to SDR 5.68 million (16.3 percent of quota). Performance criteria and structural benchmarks for 2010-11 are included in Tables 1 and 3, MEFP.

We continue to believe that the policies set forth in the attached MEFP are adequate to achieve the objectives of the program, and we stand ready to take any further measures that may become necessary to achieve our policy objectives. Lesotho will consult with the International Monetary Fund (IMF) — at its own initiative or whenever the Managing Director of the IMF requests such a consultation — on the adoption of these measures and in advance of any revisions to the policies contained in the MEFP, in accordance with the IMF's policies on such consultations.

The Government will provide the IMF with such information as the IMF may request in connection with the progress made in implementing the economic and financial policies, and 
achieving the objectives of the program. The Government authorizes the IMF to publish this letter, the attached MEFP and TMU, and the related Staff Report, including placement of these documents on the IMF website.

Yours sincerely,

$/ \mathrm{s} /$

Hon. Timothy T. Thahane,

Minister of Finance and Development Planning 


\section{Attachment II: Kingdom of Lesotho: Supplemental Memorandum of Economic and Financial Policies 2010-12}

\section{INTRODUCTION AND BACKGROUND}

1. The Government of Lesotho remains firmly committed to its medium-term program, supported by the ECF. The program was adopted in the context of large fiscal and external imbalances over the medium term as a result of a sharp drop in Southern African Customs Union (SACU) revenues, particularly in 2010/11 and 2011/12. Our policies are aimed at restoring fiscal sustainability, while limiting the adverse impact of fiscal consolidation on the poor and vulnerable groups; achieving external sustainability and broadbased growth for sustained poverty reduction; and strengthening the financial sector and the business climate.

2. This memorandum summarizes the government's assessment of progress under our program in 2010/11 and sets out our policy intentions for 2011/12. These policies are consistent with the program objectives.

\section{RECENT ECONOMIC DEVELOPMENTS}

3. Economic growth has continued to recover, but at a slower pace than projected under the program. Real GDP for 2010 is estimated at 2.4 percent, considerably lower than the 5.6 percent projected under the program. This slower pace of recovery reflects delays in implementing the Metolong Dam Project and ongoing weaknesses in the textile sector. The sector, which is our main foreign exchange earner and the largest employer outside of government, has already suffered from declining demand in the United States. The situation has been compounded by a significant appreciation of the loti, resulting in job losses and a few factory closures. At the same time, inflation fell to an average rate of about 3.8 percent in 2010, reflecting both the strong loti and lower global food prices since mid-2009-a trend which has recently been reversed.

4. The external current account position is projected to deteriorate from a broadly balanced position in 2009 to a deficit of 16.1 percent in 2010. This is mainly due to the sharp decline in SACU revenues, combined with a further widening of the trade deficit. However, thanks to our past surpluses, international reserves still cover close to five months of imports and 140 percent of M1 in 2010. 


\section{Performance Under the Program}

5. Overall performance under the program has been strong. All quantitative performance criteria for end-September 2010 were met, except for the floor on the stock of NIR which was missed by a small margin (Table 1). Implementation of structural reforms is also progressing steadily (Table 2):

- We have been closely monitoring the impact of modifications to our Integrated Financial Management Information System (IFMIS) to prevent over-commitments. A report summarizing both the problems and the measures undertaken to solve them, was completed in August, and monitoring continues.

- A new Companies Bill, which will significantly simplify the burden of starting a business, was submitted to Parliament in August.

- In October, we successfully placed M125 million of 3-year and 5-year treasury bonds in the domestic market, which was followed by a placement of M62 million in December, and a placement of M63 million in February 2011. All issues were oversubscribed.

However, we were challenged in meeting some of the structural benchmarks by the agreed dates, such as:

- The audit of user access rights in IFMIS, which was piloted in four ministries, revealed a number of systemic problems. On the basis of these findings, we prepared a report, finalized in August, with recommendations that we are implementing across all ministries.

- The submission to Cabinet of a comprehensive review of on-going capital projects was also delayed to allow for broad consultations with line ministries. The report will be submitted by end-March 2011 .

- The submission to Parliament of the Financial Institutions Act (FIA) was also delayed due to changes in consultants and the heavy legislative agenda of the Parliamentary Drafting Council Office. The Financial Institutions Bill ${ }^{1}$ will now be submitted to Parliament by end-March 2011 (structural benchmark).

\section{Fiscal performance during the first half of 2010/11 was well within program}

targets. Preliminary data for April-September ${ }^{2}$ indicate a deficit of 0.2 percent of GDP, much better than the projected 6.4 percent of GDP under the program. This largely reflects a boost in revenues by an unexpected SACU payment and a large dividend receipt from the Central

\footnotetext{
${ }^{1}$ The new legislation is now referred to as a Bill because it replaces, rather than amends, the existing Act.

2 The fiscal year runs from April to March.
} 
Bank of Lesotho (CBL), amounting together to some 6 percent of GDP. ${ }^{3}$ We built the reserves with part of these unexpected revenues, and made a once-off payment to the pension fund, which we had initially planned for 2011/12. ${ }^{4}$

7. For the remainder of FY2010/11, we have continued our ambitious consolidation effort. On this basis, we expect a deficit of 8.2 percent of GDP, compared with 19 percent of GDP projected under the program. The sharp improvement relative to the program mainly reflects the savings from the first half of the fiscal year, and broad adherence to our budgetary ceilings - though with some increase in domestic capital spending, which partially offsets the reduction in externally-funded spending from the delayed implementation of the Metolong Dam Project. The deficit is being financed through a combination of drawdown of government deposits at the CBL, budget support grants and loans from development partners, and issuance of domestic treasury bonds.

\section{Macroeconomic Policies For 2011/12}

\section{Medium-Term Program Objectives}

\section{Our medium-term program centers on adjustment to a reduction in SACU} revenues, with a particularly sharp drop of some 18 percent of GDP from 2009/10 to 2010/11 and 2011/12. The shock, which has resulted in large fiscal and external imbalances, calls for significant fiscal consolidation to restore macroeconomic stability and preserve an adequate level of international reserves in support of our exchange rate peg. The bulk of the adjustment will rely on curtailing nonproductive and nonpriority expenditure, while preserving adequate room for crucial infrastructure projects and for support to vulnerable groups. We expect that the implementation of our medium-term policy framework will restore our fiscal and external current account positions to sustainable levels that remain broadly in line with initial program projections.

\section{Macroeconomic Framework for 2011/12}

9. Lesotho's macroeconomic environment remains challenging. Real GDP is expected to grow by around 3.1 percent in 2011, driven by the MCC and Metolong Dam Projects, coupled with other public investment in infrastructure development. The associated boost in imports will further raise the external current account deficit in 2011 to 23.4 percent

\footnotetext{
${ }^{3}$ Lesotho received M466.6 million in SACU revenue following a tribunal settlement between South Africa and the BLNS over disputed shares for 2006/07-2007/08. In addition, the CBL paid dividends of M500 million from retained earnings for 2008 and 2009.

${ }^{4}$ The decision to pay during the current fiscal year came after more detailed analysis of the impact on the fiscal profile of the interest costs on this liability.
} 
of GDP. Over the medium-term, however, we expect the deficit to narrow in line with the recovery in SACU revenues and fiscal consolidation. Inflation in 2011 is projected to be 5.4 percent, broadly in line with the rate in South Africa.

\section{Fiscal Policy}

10. The main challenge for FY2011/12 ${ }^{5}$, is to meet a number of spending demands, while maintaining the momentum for medium-term fiscal consolidation:

- While we remain committed to containing the wage bill, including by freezing new positions in FY11/12, there will be a significant increase in wages and salaries, partly as a result of inclusion of new positions for the Army and the Police. A large part of the increase reflects adjustments in teachers' salaries following the introduction of a new salary scale consistent with the provisions of the new Education Act. The new scale will bring teachers' salaries more in line with those of public servants and is intended to address our difficulties in retaining qualified teachers. In addition, provisions will be made for an across-the-board salary adjustment of 5 percent, below the expected rate of inflation.

- The budget will also need to accommodate priority spending on infrastructure to support sustained economic development for poverty reduction. In this context, capital expenditure will be slightly higher in FY2011/12, relative to FY2010/11. The focus will be on high-priority developmental projects and the construction of the Metolong Dam to secure our medium- and long-term water supply. To ensure effective use of public resources, we will seek to better prioritize our investment spending through improved monitoring and evaluation, drawing on the recommendations of our Project Appraisal Committee.

- Support to the poor and most vulnerable members of society remains a matter of priority for the Government. We will maintain the floor on social spending under the program at M680 million, to ensure that efforts to strengthen fiscal consolidation do not compromise support to priority areas such as the school feeding program, old age pensions, and HIV/AIDS.

- Additional expenses will arise from conducting the local and national government elections during the coming fiscal year. We will firmly resist spending pressures that are not directly related to the cost of organizing and conducting the elections.

Notwithstanding these demands on our fiscal resources, some of which are temporary, we recognize that fiscal consolidation must be sustained to preserve our program objectives.

\footnotetext{
${ }^{5}$ The FY2011/12 budget was tabled in Parliament on February 14, 2011.
} 
11. In support of these objectives, we intend to keep tight control on other spending. This means that higher wages and salaries, and the once-off expenditure for elections (estimated at 1.5 percent of GDP), will be partially offset by savings in other recurrent expenditure. To this effect, the Government will place tight limits on appropriations for goods and services and will freeze new positions, with the exception of the Army and the Police, while eliminating non-priority posts vacated for more than a year-a practice that we are already following.

12. As part of the fiscal consolidation effort, we will also continue to strengthen nonSACU revenues by further improving tax administration and compliance. We will be building on the significant progress that has been made, with technical assistance from the U.S. Treasury Department, to strengthen tax collection, provide improved services to taxpayers and improve the operational efficiency of the Lesotho Revenue Authority. The automation of our cashier system at the border posts will also help to improve revenue collection. We are also taking steps to increase domestic non-tax revenue through a review of existing fees and charges to bring them to levels commensurate with the cost of providing the services. Nevertheless, the overall revenue ratio is expected to fall this year as a result of lower SACU revenues and CBL dividends, implying an increase in the projected fiscal deficit to about 15 percent of GDP.

\section{To ensure debt sustainability, the government will continue to seek external} financing through grants and concessional loans and save any unplanned inflows. As agreed with the IMF, non-concessional financing will be limited to the European Investment Bank loan for the Metolong Dam Project, in the short term. In addition, we are assessing options for the medium-term financing of the second phase of the Lesotho Highlands Water Project, which is unlikely to be available on concessional terms only. Consistent with the current practice, the part of the deficit in 2011/12 that is not covered by external flows, will be financed by drawing down our deposits at the CBL and issuing additional domestic government bonds of M500 million. In the event that fiscal performance is better than expected, including as a result of higher-than-programmed SACU receipts, the available resources will be used to build up our deposits at the CBL, while a further drawdown would be required in the event of shortfalls in SACU receipts or budget support.

\section{Public Financial Management}

\section{Further fiscal consolidation over the medium term will need to be based on an} explicit understanding of priorities. We will undertake a comprehensive review of recurrent expenditure, with a view of identifying those that are of low priority and can be eliminated. In addition, we will develop a time-bound plan for capacity building in ministries to strengthen their preparation of medium-term expenditure frameworks, by end-June 2011 (structural benchmark). 


\section{Public Financial Management (PFM) reforms, supported by development} partners, will continue to improve the efficiency of our budget process. Steady progress has been made but challenges remain, including problems with the functionality of IFMIS. In 2011/12, we will implement measures to strengthen expenditure controls, improve revenue tracking and enhance accountability. Activities will focus on further improvements in the functionality of IFMIS, resolving interface and other IFMIS problems, and increasing staff training in the use of the system. To help improve revenue tracking, by end-September 2011, we will implement a front office revenue receipting system and ensure that all revenues are captured in the IFMIS (structural benchmark).

16. The accumulation of domestic arrears remains a concern. We intend to complete a full audit, by end-June 2011, to determine the size and develop a time-bound plan to eliminate these arrears (structural benchmark). We are also committed to prevent the emergence of new domestic arrears in the future, by developing and implementing processes that ensure timely payment.

\section{Mitigating Financial Sector Risks and Supporting Development}

17. The government is moving ahead with financial sector reforms. While our banks remain well capitalized, profitable and liquid, vulnerabilities in our financial system stem from weakly supervised nonbank financial institutions (NBFIs). Reforms are underway to strengthen the institutional and regulatory framework for all financial institutions, while enhancing access to financial services, particularly for rural areas. Measures include:

- Submitting to Parliament the new Financial Institutions Bill, which incorporates amendments to deal with supervision of NBFIs by the CBL, and unlawful business practices, including Ponzi schemes, by end-March 2011 (structural benchmark).

- Submitting to Cabinet a review of the Cooperatives Societies Act, by end-March 2011, with a view to ensuring that cooperatives who accept deposits from the public comply with and are registered under the FIA, and are therefore subjected to CBL supervision and the same prudential and anti-money laundering requirements as banks (structural benchmark).

- Completing the draft regulations for the scope and mandate of the Financial Intelligence Unit and the AML regime.

- Advancing the modernization of Postbank, to better enable it to expand its services and products to individuals and small and medium-size enterprises, including those in rural areas. To this end, we will prepare a time-bound plan for expansion of microlending products and services by Postbank, including introduction of smartcards. 
- Launching a Partial Credit Guarantee Scheme by end-March 2011, and submitting to Cabinet a National Leasing Finance proposal by end-June 2011 (both structural benchmarks) to enhance access to financial services.

\section{Improving Productivity and The Investment Climate}

18. We will also continue improving our business climate to support private sectorled growth and diversify our economy. The uncertainties arising from the serious difficulties in the textile sector reinforce the need to fast-track the reforms. A number of reforms aimed at improving the business environment have been implemented, and several are underway. The recently amended Land Reform Act provides security of tenure to use land as an economic assets that can be used as collateral to access financing for investment. The new Companies Bill, once it is passed by Parliament, will significantly reduce the time and cost of setting up a business. In addition, the automation of the Companies Registry and the implementation of a new business plan for the One Stop Business Facilitation Centre will help the ease of doing business in Lesotho. The Government is fully aware that despite these achievements, more needs to be done to improve Lesotho's business climate and competitiveness. Among the next steps, we intend to submit the Industrial Licensing Bill to Parliament by end-March 2011 (structural benchmark), and we will continue to work closely with our development partners to implement reforms that strengthen private sector development and economic diversification.

\section{Poverty Reduction Strategy}

19. Lesotho's Interim National Development Framework (INDF) (2008/09-2010/11) is based on the priorities and objectives contained in the original Poverty Reduction Strategy Paper (PRSP) (2004/05-2007/08) and Vision 2020. The INDF is a precursor to a comprehensive five-year National Strategic Development Plan (NSDP), which is planned to be implemented starting 2012/13, and focuses on diversifying the economy to achieve sustained economic growth and generate alternative employment opportunities for Basotho.

\section{SAFEguARD ASSESSMent}

\section{We remain committed to implementing the recommendations of the recently} completed safeguards assessment of the CBL, which updates the previous assessment completed in 2003. The current assessment concluded that key elements of the CBL's safeguards framework have been strengthened since the 2003 assessment, but also that risks exist in the external audit mechanism. We commit to taking the necessary steps to appoint an international audit firm as the CBL's sole auditor, including by waiving the residency and registration requirements contained in the Accountants Act of 1977. 


\section{Program Monitoring}

21. Completion of the second and third reviews of the arrangement, by August 24, 2011 and February 24, 2012, respectively, will be based on the observance of quantitative performance criteria through end-March 2011 and end-September 2011, respectively (Table 1). The targets for end-June 2011 will be indicative. The definitions of the variables monitored as quantitative performance criteria are provided in the Technical Memorandum of Understanding (TMU).

The Government is committed to ensuring that the program remains on track, and will continue to monitor implementation. 
Table 1. Lesotho: Quantitative Performance Criteria, Benchmarks, and Indicative Targets

September 2010 - September 2011

\begin{tabular}{|c|c|c|c|c|c|c|c|c|c|}
\hline & \multicolumn{7}{|c|}{ FY2010/11 } & \multicolumn{2}{|c|}{ FY2011/12 } \\
\hline & \multicolumn{3}{|c|}{ September } & \multicolumn{2}{|c|}{ December } & \multirow{2}{*}{$\begin{array}{c}\text { March } \\
\text { Perf. Criteria } \\
\end{array}$} & \multirow{2}{*}{$\begin{array}{l}\text { Revised March } \\
\text { Perf. Criteria }^{7} \\
\end{array}$} & \multirow{2}{*}{$\begin{array}{c}\text { June } \\
\text { Benchmarks } \\
\end{array}$} & \multirow{2}{*}{$\begin{array}{c}\text { September } \\
\text { Perf. Criteria } \\
\end{array}$} \\
\hline & Perf. Criteria & Actual & Status & Benchmarks & Prel. & & & & \\
\hline & \multicolumn{9}{|c|}{ (In millions of Maloti) } \\
\hline Ceiling on the domestic financing & & & & & & & & & \\
\hline requirement of the central government ${ }^{1,2,3}$ & 311.5 & & & 780 & & 1,877 & 1,453 & 822 & 1,435 \\
\hline Adjusted benchmark ${ }^{4}$ & 765.6 & 620.1 & Met & 967 & 440 & & & & \\
\hline \multicolumn{10}{|l|}{ Ceiling on the net domestic assets } \\
\hline of the Central Bank of Lesotho 1, 2,3 & $1,884.0$ & & & 1,752 & & 3,032 & 1,335 & 860 & 1,314 \\
\hline Adjusted benchmark ${ }^{4}$ & $1,539.4$ & 817.2 & Met & 1,141 & 597 & & & & \\
\hline & \multicolumn{9}{|c|}{ (In millions of US dollars) } \\
\hline Floor on the stock of net international & & & & & & & & & \\
\hline $\begin{array}{c}\text { reserves of the Central Bank of Lesotho }{ }^{2,3} \\
\text { Adjusted benchmark }\end{array}$ & $\begin{array}{l}956 \\
938\end{array}$ & 933 & Not met & 884 & 956 & 827 & 805 & 692 & 634 \\
\hline \multicolumn{10}{|l|}{$\begin{array}{l}\text { Ceiling on the amount of new non- } \\
\text { concessional external debt contracted or } \\
\text { guaranteed by the public sector (cumulative } \\
\text { from end-March } 2010^{2,5}\end{array}$} \\
\hline Maturity of less than one year & 0 & 0 & Met & 0 & 0 & 0 & 0 & 0 & 0 \\
\hline Maturity of one year or more ${ }^{6}$ & 182 & 182 & Met & 182 & 182 & 182 & 182 & 182 & 182 \\
\hline $\begin{array}{l}\text { Ceiling on the stock of external payments } \\
\text { arrears }{ }^{5}\end{array}$ & 0 & 0 & Met & 0 & 0 & 0 & 0 & 0 & 0 \\
\hline & \multirow{2}{*}{\multicolumn{9}{|c|}{ (In millions of Maloti) }} \\
\hline Indicative targets: & & & & & & & & & \\
\hline Floor on the central government social expenditures ${ }^{7}$ & 170 & 253 & Met & 170 & 174 & 170 & 170 & 170 & 170 \\
\hline Ceiling on gross cumulative payments of domestic arrears ${ }^{1}$ & 200 & 199 & Met & 200 & 199 & 200 & $\ldots$ & $\ldots$ & $\ldots$ \\
\hline \multicolumn{10}{|l|}{ Memo items: } \\
\hline Net disbursements 1,2 & 198.9 & 69.5 & & 208.0 & 206.1 & 396.3 & 303.5 & -2.3 & -18.0 \\
\hline General budget support & 358.0 & 204.1 & & 448.0 & 389.6 & 718.0 & 552.4 & 55.6 & 154.4 \\
\hline Debt service payments & 159.1 & 134.6 & & 240.0 & 183.5 & 321.7 & 248.8 & 57.9 & 172.4 \\
\hline Unused outstanding Metolong balances ${ }^{1}$ & $1,123.4$ & 0.0 & & 984.2 & 0.0 & $1,144.4$ & 0.0 & 0.0 & 0.0 \\
\hline Metolong loan disbursement & $1,370.9$ & 2.4 & & $1,370.9$ & 2.4 & $1,716.6$ & 151.3 & 140.3 & 140.3 \\
\hline Use of Metolong loan & 247.5 & 2.4 & & 386.8 & 2.4 & 572.2 & 151.3 & 140.3 & 140.3 \\
\hline Payment of domestic arrears ${ }^{1}$ & 200.0 & 198.8 & & 200.0 & 198.8 & 200.0 & 198.8 & 200.0 & 200.0 \\
\hline
\end{tabular}

Sources: Ministry of Finance and Development Planning; Central Bank of Lesotho; and Fund staff estimates.

${ }^{1}$ Values are cumulative from end of previous fiscal year

2 Definitions and program adjusters are specified in the TMU.

${ }^{3}$ Excludes unused outstanding balances from the EIB loan for the Metolong dam.

${ }^{4}$ Adjustments for September and December 2010 include corrections to program assumptions on the treatment of Metolong balances

${ }^{5}$ Continuous performance criteria

${ }^{6}$ New nonconcessional borrow ing is limited to financing the Metolong dam

7 Covers quarterly spending on school feeding program, old age pension and HIV/AIDS 
Table 2. Lesotho Structural Benchmarks for FY2010/11

\begin{tabular}{|c|c|c|}
\hline Structural Benchmarks & Test Date & Status \\
\hline \multicolumn{3}{|l|}{ I. Public Financial Management } \\
\hline $\begin{array}{l}\text { Prepare monthly monitoring reports assessing } \\
\text { the impact of modification to the IFMIS to } \\
\text { prevent over-commitment. }\end{array}$ & End-Sept. 2010 & $\begin{array}{l}\text { Met. A Quality Assurance Report was also } \\
\text { completed in August }\end{array}$ \\
\hline $\begin{array}{l}\text { Complete an audit of user access rights to the } \\
\text { IFMIS and assign user access rights on a "need- } \\
\text { to-use" basis }\end{array}$ & End-June 2010 & $\begin{array}{l}\text { Not met but implemented with delay. A preliminary } \\
\text { report was completed July 9th and the final report } \\
\text { Aug 6th }\end{array}$ \\
\hline $\begin{array}{l}\text { Submit to Cabinet a comprehensive review of } \\
\text { all on-going capital projects, assessing their } \\
\text { desirability and make recommendations on } \\
\text { projects to be retained or eliminated }\end{array}$ & End-Sept. 2010 & $\begin{array}{l}\text { Not met. Delayed to allow broad consultation with } \\
\text { line ministries. Draft report completed and to be } \\
\text { submitted to Cabinet by end-March } 2011\end{array}$ \\
\hline \multicolumn{3}{|l|}{ II. Structural Reforms } \\
\hline Submit the Companies Bill to Parliament & End-Sept. 2010 & Met \\
\hline \multicolumn{3}{|l|}{ III. Financial Sector Regulation } \\
\hline Issue domestic bonds & End-Dec 2010 & $\begin{array}{l}\text { Met. Institutional infrastructure was in place by } \\
\text { August and bond issuance began in October }\end{array}$ \\
\hline $\begin{array}{l}\text { Submit the amended Financial Institutions Act } \\
\text { to Parliament }\end{array}$ & End-Sept. 2010 & $\begin{array}{l}\text { Not met. Proposed as an end-March } 2011 \\
\text { benchmark }\end{array}$ \\
\hline
\end{tabular}


Table 3. Structural Benchmarks through September 2011

\begin{tabular}{|c|c|c|}
\hline Benchmarks & Test date & Macroeconomic rationale \\
\hline \multicolumn{3}{|l|}{ I. Public Financial Management } \\
\hline $\begin{array}{l}\text { Complete an audit of domestic arrears and prepare a time } \\
\text { bound plan for elimination }\end{array}$ & End-March 2011 & $\begin{array}{l}\text { Support expenditure control and } \\
\text { medium-term fiscal consolidation }\end{array}$ \\
\hline $\begin{array}{l}\text { Prepare a time bound plan for capacity building in line } \\
\text { ministries to strengthen preparation of MTEF by all ministries }\end{array}$ & End-June 2011 & $\begin{array}{l}\text { Support expenditure control and } \\
\text { medium-term fiscal consolidation }\end{array}$ \\
\hline $\begin{array}{l}\text { Implement the front office revenue receipting system and } \\
\text { ensure that all revenues are captured in the IFMIS }\end{array}$ & End-September 2011 & $\begin{array}{l}\text { Strengthen revenue tracking and } \\
\text { support medium-term fiscal } \\
\text { consolidation }\end{array}$ \\
\hline \multicolumn{3}{|l|}{ II. Financial Sector Regulation } \\
\hline $\begin{array}{l}\text { Submit to Cabinet a review of the Cooperatives Societies } \\
\text { Act with a view to ensuring that all financial institutions that } \\
\text { accept deposits from the public comply with and are } \\
\text { registered under the FIA }\end{array}$ & End-March 2011 & $\begin{array}{l}\text { Strengthen prudential regulations and } \\
\text { reduce systemic risks to the domestic } \\
\text { financial sector }\end{array}$ \\
\hline $\begin{array}{l}\text { Submit to Parliament the new Financial Institutions Bill, which } \\
\text { incorporates amendments to deal with supervision of NBFls } \\
\text { by the CBL, and unlawful business practices, including Ponzi } \\
\text { schemes }\end{array}$ & End-March 2011 & $\begin{array}{l}\text { Strengthen prudential regulations and } \\
\text { reduce systemic risks to the domestic } \\
\text { financial sector }\end{array}$ \\
\hline $\begin{array}{l}\text { Launch a Partial Credit Guarantee Scheme, aimed at } \\
\text { reducing the risks for banks to lend to small and medium- } \\
\text { sized enterprises }\end{array}$ & End-March 2011 & $\begin{array}{l}\text { Improve access to financing for small } \\
\text { and medium-sized enterprises }\end{array}$ \\
\hline $\begin{array}{l}\text { Submit to Cabinet the National Leasing Finance proposal, } \\
\text { aimed at creating a legal environment conducive to leasing, } \\
\text { by supplementing the } 1974 \text { Hire Purchase Act. }\end{array}$ & End-June 2011 & $\begin{array}{l}\text { Improve access to financing for small } \\
\text { and medium-sized enterprises }\end{array}$ \\
\hline \multicolumn{3}{|l|}{ III. Other Structural Reforms } \\
\hline $\begin{array}{l}\text { Submit to Parliament the Industrial Licensing Bill, which will } \\
\text { improve the process of licensing industrial enterprises }\end{array}$ & End-March 2011 & $\begin{array}{l}\text { Improve the business climate to } \\
\text { facilitate private sector-led growth, and } \\
\text { increase productivity and } \\
\text { competitiveness }\end{array}$ \\
\hline
\end{tabular}




\title{
Attachment III: Kingdom of Lesotho-Technical Memorandum of Understanding
}

\author{
February 24, 2011
}

1. This memorandum sets forth the understandings between the government of Lesotho and the IMF staff regarding the definitions of the quantitative performance criteria and benchmarks for the second review of its arrangement supported under the ECF-supported program, as well as the respective reporting requirements. These performance criteria and benchmarks are reported in Table 1 of the government's Memorandum of Economic and Financial Policies (MEFP).

\section{A. Ceiling on the Domestic Financing Requirement (DFR) of the Central Government}

2. Definition. The central government includes the central administration and all district administrations. The domestic financing requirement of the central government is defined as net credit to the government from the banking system (that is, the Central Bank of Lesotho and the commercial banks) plus holdings of treasury bills and other government securities by the nonbank sector. For program monitoring purposes, the domestic financing requirement will be calculated as the change from the end of the previous fiscal year (which runs from April 1 to March 31) of net credit to the government by the banking system and of holdings of treasury bills and other government securities by the nonbank sector. In particular, the calculation of the domestic financing requirement shall include changes in (i) balances held in the privatization account or balances of other accounts into which proceeds from the sale of public enterprises are deposited; (ii) the amount of outstanding treasury bills issued by the Central Bank of Lesotho for monetary policy purposes and held in the balance of the blocked government deposit account used by the Central Bank of Lesotho to sterilize reserve money absorbed by monetary policy operations. The calculation of the domestic financing requirement shall exclude changes in balances held in any account into which revenues collected by the customs department are held pending their transfer to the SACU revenue pool. External debt service, amortization, disbursements and external grants will be calculated at an exchange rate of M 7.33 per U.S. dollar.

3. Supporting material. The Central Bank of Lesotho will provide the monetary survey and other monthly monetary statistics, as well as a table showing the details of all government financing operations from the nonbank public, on a monthly basis and within 30 days of the end of the month. The following information will be presented as memorandum items in the monetary survey: (i) the outstanding balances in the privatization account or accounts; and (ii) details of any monetary operations with treasury bills, including changes in government deposits as a result of such operations. The Central Bank of Lesotho will also provide a table showing the details of government debt by type and holder. The 
Ministry of Finance and Development Planning will provide detailed monthly budget operation reports and tax arrears reports.

\section{B. Ceiling on the Stock of Net Domestic Assets of the Central Bank of Lesotho}

4. Definition. The net domestic assets (NDA) of the Central Bank of Lesotho are defined as the difference between reserve money (currency in circulation plus total bank deposits at the central bank) and NFA (as defined in paragraph 5). For program monitoring purposes, the NDA will be calculated as the change from the end of the previous fiscal year (which runs from April 1 to March 31). The NDA thus includes net claims by the Central Bank of Lesotho on the government (loans and treasury bills purchased less government deposits), claims on banks, and "other items net" (other assets, other liabilities, and the capital account).

5. Definition. The net foreign assets (NFA) of the Central Bank of Lesotho are defined as foreign assets minus foreign liabilities, and include all foreign claims and liabilities of the central bank. The values of all foreign assets and liabilities will be calculated in U.S. dollars at the end of each quarter using the program exchange rates.

6. Supporting material. The Central Bank of Lesotho will provide detailed data on its balance sheet on a monthly basis within 21 days of the end of the month. The central bank will also provide a table of selected monetary indicators covering the major elements of its balance sheet on a weekly basis.

\section{Floor on the Stock of Net International Reserves of the Central Bank of Lesotho}

7. Definition. The net international reserves (NIR) are defined as the Central Bank of Lesotho's liquid, convertible foreign assets minus its convertible foreign liabilities. Pledged or otherwise encumbered assets, including, but not limited to, assets used as collateral or as guarantee for third-party external liabilities are excluded from reserve assets. Reserve assets include cash and balances held with banks, bankers' acceptances, investments, foreign notes and coins held by the Central Bank of Lesotho, Lesotho's reserve position in the Fund, and SDR holdings. Reserve liabilities include nonresident deposits at the Central Bank of Lesotho, use of IMF credit, and any other short term liabilities of the central bank to nonresidents. The stock of NIR at the end of each quarter is defined in U.S. dollars and will be calculated using the program exchange rates. ${ }^{1}$

\footnotetext{
${ }^{1}$ Program cross exchange rates are: South African rand per U.S. dollar: 7.3; U.S. dollars per pound sterling: 1.5; U.S. dollars per euro: 1.3; Swiss francs per U.S. dollar: 1.1; Swedish kronor per U.S. dollar: 7.3; and Botswana pula per U.S. dollar: 6.8. SDR per U.S.dollar: 0.648; Program maloti per U.S. dollar exchange rate: 7.3.
} 
8. Supporting material. The Central Bank of Lesotho will provide data on its NIR on a monthly basis within three weeks of the end of the month. The NIR data will be provided in a table showing the currency breakdown of the reserve assets and reserve liabilities of the Central Bank of Lesotho converted into U.S. dollars and maloti at the program exchange rates.

\section{Ceiling on the Amount of New Nonconcessional External Debt Contracted or Guaranteed by the Public Sector, with Original Maturity of One Year or More}

9. Definition. For purposes of the ECF, concessionality requirements will be applied to foreign-currency denominated debt regardless of the residency of the creditor. The public sector comprises the central government, the Central Bank of Lesotho, and all public enterprises and other official sector entities with majority state ownership. This performance criterion applies not only to debt as defined in point No. 9 of the Guidelines on Performance Criteria with Respect to External Debt in Fund Arrangements, adopted by Decision No. 6230-(79/140), as revised on August 24, 2000, as amended effective December 1, 2009, but also to commitments contracted or guaranteed for which value has not been received. Included in this performance criterion are all current liabilities that are created under a contractual arrangement through the provision of value in the form of assets (including currency) or services, and that require the public sector (obligor) to make one or more payments in the form of assets (including currency) at some future point(s) in time to discharge principal and/or interest liabilities incurred under the contract. In effect, all instruments that share the characteristics of debt as described above (including loans, suppliers' credits, and leases) will be subject to the ceiling. New nonconcessional borrowing is limited to the Metolong Dam Project, a high-return public investment project. The performance criterion will be evaluated on a continuous basis as the cumulative change in the amount of new nonconcessional debt contracted or guaranteed from end-March 2010 onward.

10. Definition. A loan is concessional if its grant element is at least 35 percent of the value of the loan, calculated using a discount rate based on commercial interest reference rates (CIRRs) reported by the OECD. For loans of maturity of greater than 15 years, the grant element will be based on the ten-year average of OECD CIRRs. For loans of maturity of 15 years or less, the grant element will be based on the six-month average of OECD CIRRs. Margins for differing repayment periods would be added to the CIRRs: 0.75 percent for repayment periods of less than 15 years, 1 percent for repayment periods of 15 to 19 years, 1.15 percent for repayment periods of 20 to 29 years, and 1.25 percent for repayment periods of 30 years or more.

11. Supporting material. Details of all new commitments and government guarantees for external borrowing, with detailed explanations, will be provided by the Ministry of 
Finance and Development Planning on a monthly basis within 30 days of the end of the month.

\section{E. Ceiling on the Amount of New External Debt Contracted or Guaranteed by the Public Sector, with Original Maturity of Less than One Year}

12. Definition. The public sector comprises the central government, the Central Bank of Lesotho, and all enterprises with majority state ownership. This performance criterion applies not only to debt as defined in point No. 9 of the Guidelines on Performance Criteria with Respect to External Debt in Fund Arrangements, adopted by Decision No. 6230-(79/140), as revised on August 24, 2000, as amended effective December 1, 2009, but also to commitments contracted or guaranteed for which value has not been received. Included in this performance criterion are all current liabilities that are created under a contractual arrangement through the provision of value in the form of assets (including currency) or services, and that require the public sector (obligor) to make one or more payments in the form of assets (including currency) at some future point(s) in time to discharge principal and/or interest liabilities incurred under the contract. In effect, all instruments that share the characteristics of debt as described above (including loans, suppliers' credits, and leases) will be subject to the ceiling. Excluded from this performance criterion are normal short-term import credits. The performance criterion will be evaluated on a continuous basis as the cumulative change in the amount of new nonconcessional debt contracted or guaranteed from the end of the previous fiscal year (March 31).

13. Supporting material. Details of all new commitments and government guarantees for external borrowing, with detailed explanations, will be provided by the Ministry of Finance and Development Planning on a monthly basis within 30 days of the end of the month.

\section{F. Ceiling on the Stock of External Payments Arrears}

14. Definition. During the period of the arrangement, the stock of external payments arrears of the public sector (central government, Central Bank of Lesotho, and all enterprises with majority state ownership) will continually remain zero. Arrears on external debt-service obligations include any nonpayment of interest and/or principal in full and on time falling due to all creditors, including the IMF and the World Bank.

15. Supporting material. Details of arrears accumulated on interest and principal payments to creditors will be reported within one week from the date of the missed payment. 


\section{G. Floor on the Central Government Social Expenditures}

16. Definition: There will be a floor on the central government social expenditures. The observance of this floor is an indicative target. Social expenditures comprise spending on the following programs: school feeding program, old age pension, and HIV/AIDS.

17. Supporting material: Data on social spending will be compiled by the Ministry of Finance and Development Planning and will be provided on a quarterly basis, to be submitted no later than six weeks after the end of each reporting period.

\section{H. Adjusters}

18. The quantitative performance criteria specified under the program are subject to the following adjusters:

\section{A. Southern African Customs Union Revenues}

- $\quad$ The program targets for the NDA in any quarter will be adjusted downward (upward) by the full amount of any excess (shortfall) in receipts from the Southern Africa Customs Union (SACU) relative to the programmed levels specified in Table 1 of the MEFP as well as any SACU advance receipts in that quarter, where such advance receipts constitute amounts that would otherwise have been received in a subsequent quarter.

- $\quad$ The program targets for the DFR in any quarter will be adjusted downward (upward) by the full amount of any excess (shortfall) in receipts from the Southern Africa Customs Union (SACU) relative to the programmed levels specified in Table 1 of the MEFP as well as any SACU advance receipts in that quarter, where such advance receipts constitute amounts that would otherwise have been received in a subsequent quarter.

- $\quad$ The program targets for the NIR in any quarter will be adjusted upward (downward) by the full amount of any excess (shortfall) in receipts from the Southern Africa Customs Union (SACU) relative to the programmed levels specified in Table 1 of the MEFP as well as any SACU advance receipts in that quarter, where such advance receipts constitute amounts that would otherwise have been received in a subsequent quarter.

19. Supporting material: The Central Bank of Lesotho will provide data on SACU receipts on a quarterly basis within the first month of the quarter. 


\section{B. Budgetary Support net of Debt Service ${ }^{2}$}

- $\quad$ The ceiling on the NDA will be adjusted downward (upward) by the full amount of the excess (shortfall) in budgetary support net of debt service relative to the programmed levels specified in Table 1 of the MEFP.

- $\quad$ The ceiling on the DFR will be adjusted downward (upward) by the full amount of the excess (shortfall) in budgetary support net of debt service relative to the programmed levels specified in Table 1 of the MEFP.

- $\quad$ The floor on the NIR of the Central Bank of Lesotho will be adjusted upward (downward) by the full amount of the excess (shortfall) in budgetary support net of debt service relative to the programmed levels specified in Table 1 of the MEFP.

20. Supporting material: Data on budget support and debt service will be compiled by the Ministry of Finance and Development Planning and will be provided on a quarterly basis, to be submitted no later than six weeks after the end of each reporting period.

\section{Payment of Domestic Arrears ${ }^{3}$}

- $\quad$ The ceilings on the NDA will be adjusted upward (downward) by the full amount of the excess (shortfall) in payments of arrears relative to the programmed levels specified in Table 1 of the MEFP.

- $\quad$ The ceilings on the DFR will be adjusted upward (downward) by the full amount of the excess (shortfall) in payments of arrears relative to the programmed levels specified in Table 1 of the MEFP.

- $\quad$ The floor on the NIR of the Central Bank of Lesotho will be adjusted downward (upward) by the full amount of the excess (shortfall) in payment of arrears relative to the programmed levels specified in Table 1 of the MEFP.

\footnotetext{
${ }^{2}$ General budget support consists of grants and loans received by the Central Government for financing its overall policy and budget priorities.

${ }^{3}$ Domestic arrears are overdue payment obligations of the central government other than external payment arrears, including on wages and salaries, pensions, transfers, domestic interest, goods and services, obligations arising from court cases, legally established compensation claims, and tax refunds. Payments on wages and salaries, pensions, transfers, court-established obligations, and compensations are in arrears when they remain unpaid for more than 45 days beyond their due date. Domestic interest payments are in arrears when the payment is not made on the due date. Payments for goods and services are deemed to be in arrears if they have not been made within 45 days of the date of invoice, or - if a grace period has been agreed — within the contractually agreed grace period.
} 
21. Supporting material: Data on domestic arrears will be compiled by the Ministry of Finance and Development Planning and will be provided on a quarterly basis, to be submitted no later than six weeks after the end of each reporting period. 


\section{INTERNATIONAL MONETARY FUND}

KINGDOM OF LESOTHO

\section{First Review Under the Three-Year Extended Credit Facility Arrangement and Requests for Waiver of} Nonobservance of Performance Criterion and Modification of Performance Criteria

\section{Informational Annex}

Prepared by the African Department in Consultation with Other Departments Approved by Domenico Fanizza and Tom Dorsey

March 18, 2011

- Relations with the Fund. Describes financial and technical assistance by the IMF, and provides information on the exchange rate system. Lesotho's last Fund arrangement, a PRGF, expired in 2004.

- The JMAP Bank-Fund. Describes the priorities and main activities of the World Bank Group and the IMF, and areas of cooperation in their work with the authorities of Lesotho.

- $\quad$ Statistical Issues. Assesses the quality of statistical data. Economic data are adequate for surveillance purposes, though some deficiencies remain. Lesotho subscribes to the GDDS. 


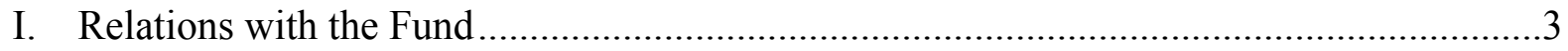

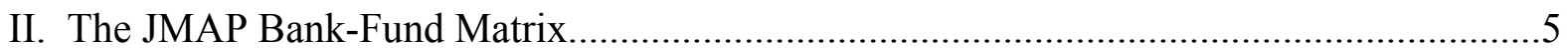

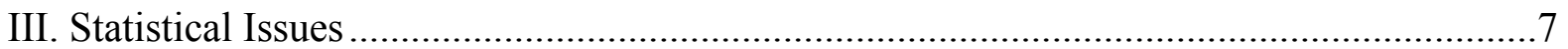




\section{LESOTHO: RELATIONS WITH THE FUND}

(As of February 28, 2011)

I. Membership status: Joined 07/25/1968; accepted the obligations of Article VIII, Sections 2, 3, and 4: 03/05/1997.

II. General resources account:

Quota

Fund holdings of currency

Reserve position in Fund

III. SDR Department:

Net cumulative allocation

Holdings

IV. Outstanding purchases and loans:

$\mathrm{ECF}^{1}$ arrangements $\underline{\text { SDR Million }}$

34.90

31.32

3.61

$\underline{\text { SDR Million }}$

32.88

33.47

$\underline{\text { SDR Million }}$

17.60

$\underline{\text { Percent Quota }}$

50.43

V. Financial arrangements:

$\begin{array}{lcccc}\text { Type } & \begin{array}{c}\text { Approval } \\ \text { Date }\end{array} & \begin{array}{c}\text { Expiration } \\ \text { Date }\end{array} & \begin{array}{c}\text { Amount Approved } \\ \text { (SDR Million) }\end{array} & \begin{array}{c}\text { Amount Drawn } \\ \text { (SDR Million) }\end{array} \\ \text { ECF } & 06 / 02 / 2010 & 06 / 01 / 2013 & \frac{41.88}{7.80} \\ \text { ECF }^{1} & 03 / 09 / 2001 & 10 / 31 / 2004 & 24.50 & 24.50 \\ \text { Stand-By } & 09 / 23 / 1996 & 9 / 22 / 1997 & 7.17 & 0.0 \\ \text { Stand-by } & 07 / 31 / 1995 & 7 / 30 / 1996 & 7.17 & 0.0\end{array}$

\footnotetext{
${ }^{1}$ Formerly PRGF.
} 
VI. Projected obligations to fund (SDR million; based on existing use of resources and present holdings of SDRs):

\begin{tabular}{lllll}
\multicolumn{5}{c}{ Forthcoming } \\
& $\underline{2012}$ & $\underline{2013}$ & $\underline{2014}$ & $\underline{2015}$ \\
3.85 & 3.15 & 1.75 & 1.05 & 0.78 \\
0.00 & 0.03 & 0.02 & 0.02 & 0.02 \\
$\mathbf{3 . 8 5}$ & $\mathbf{3 . 1 8}$ & $\mathbf{1 . 7 7}$ & $\mathbf{1 . 0 7}$ & $\mathbf{0 . 8 0}$
\end{tabular}

VII. An updated safeguards assessment under the 2010 ECF arrangement was completed on December 27, 2010. The assessment concluded that the CBL has strengthened key elements of its safeguards framework since the 2003 assessment. International Financial Reporting Standards have been fully implemented, and the CBL has introduced web-based publication of the audited financial statements. Comprehensive investment guidelines have been formalized and the statutory governance framework has also been strengthened through the adoption of by-laws. Risks exist in the external audit mechanism, however, and effective audit and control oversight remains a challenge. Controls over the compilation of monetary program data should also be strengthened. The CBL has commenced on the implementation of key recommendations and has committed to the appointment of an international audit firm as the CBL's sole auditor.

\section{Exchange arrangement:}

Lesotho's currency, the loti (plural maloti), is pegged to the South African rand at par. Both the loti and rand are legal tenders. As of March 8, 2011, the maloti rate per U.S. dollar was M 6.9196.

\section{Article IV consultation:}

The 2009 Article IV consultation was concluded by the Executive Board on February 22, 2010. Lesotho is on the standard 12-month Article IV consultation cycle.

\section{$X$. Technical assistance missions:}

Monetary policy implementation

Public accounts

General Data Dissemination System (GDDS) project for Anglophone Africa

Balance of payments

Monetary policy and AML/CFT

Government finance statistics

National accounts

National accounts statistics

GDDS project for Anglophone Africa

$\begin{array}{lll}\text { MAE } & \text { short-term } & 2001 \\ \text { FAD } & \text { short-term } & 2002 \\ \text { STA } & \text { short-term } & 2002 \\ & & \\ \text { STA } & \text { short-term } & 2002 \\ \text { MFD } & \text { short-term } & 2003 \\ \text { STA } & \text { short-term } & 2003 \\ \text { STA } & \text { short-term } & 2003 \\ \text { STA } & \text { short-term } & 2004 \\ \text { STA } & \text { short-term } & 2004\end{array}$


Legislative drafting/FIU

Monetary operations/payments issues/banking supervision

Government finance statistics/GDDS

Banking law

National accounts statistics/GDDS

Monetary operations

Payments issues

Banking law

BOP statistics/GDDS

GDDS consultation

Government Finance Statistics: GDDS Project for

Anglophone African Countries

Payment System Reform

Central Banking and Banking Law

Bank Supervision/Monetary Operations/Payments \&

Settlements

Legal drafting, AML/CFT, FIU, supervisory and institutional

Regional workshop on the statistical treatment of SACU transfers

Monetary and Financial Statistics

Nonbank supervision

Bank supervision

Monetary operations/Bank supervision

Payment systems

Government Finance Statistics: GDDS Project for

Anglophone African Countries

Money markets

Banking laws and regulation

Balance of payment

Payment systems modernization

Bank supervision

Payment systems

Money markets

Monetary and Financial Statistics

Balance of Payments

Public Financial Management

Financial sector regulations

Payment systems

Missions planned for 2011

Financial stability

Diagnostic revenue administration

Public Financial Management

SRF data development

$\begin{array}{lll}\text { LEG } & \text { Short-term } & 2005 \\ \text { MFD } & \text { short-term } & 2005 \\ \text { STA } & \text { short-term } & 2005 \\ \text { LEG } & \text { short-term } & 2005 \\ \text { STA } & \text { short-term } & 2005 \\ \text { MFD } & \text { short-term } & 2005 \\ \text { MFD } & \text { short-term } & 2005 \\ \text { LEG } & \text { short-term } & 2005 \\ \text { STA } & \text { short-term } & 2005 \\ \text { STA } & \text { short-term } & 2005 \\ \text { STA } & \text { short-term } & 2006 \\ & & \\ \text { LEG } & \text { short-term } & 2006 \\ \text { LEG } & \text { short-term } & 2006 \\ \text { MFD } & \text { short-term } & 2006 \\ \text { LEG } & \text { short-term } & 2006 \\ & & \\ \text { STA } & \text { short-term } & 2007 \\ & & \\ \text { STA } & \text { short-term } & 2007 \\ \text { MCM } & \text { short-term } & 2007 \\ \text { MCM } & \text { short-term } & 2007 \\ \text { MCM } & \text { short-term } & 2007 \\ \text { MCM } & \text { short-term } & 2007 \\ \text { STA } & \text { short-term } & 2008 \\ & & \\ \text { MCM } & \text { short-term } & 2008 \\ \text { LEG } & \text { short-term } & 2008 \\ \text { STA } & \text { short-term } & 2008 \\ \text { MCM } & \text { short-term } & 2008 \\ \text { MCM } & \text { short-term } & 2008 \\ \text { MCM } & \text { short-term } & 2008 \\ \text { MCM } & \text { short-term } & 2009 \\ \text { STA } & \text { short-term } & 2009 \\ & & \\ \text { STA } & \text { short-term } & 2010 \\ \text { FAD } & \text { short-term } & 2010 \\ \text { LEG } & \text { short-term } & 2010 \\ \text { MCM } & \text { short-term } & 2010 \\ & & \\ \text { MCM } & \text { short-term } & 2011 \\ \text { FAD } & \text { short-term } & 2011 \\ \text { STA } & \text { short-term } & 2011 \\ & \text { short-term } & 2011\end{array}$

\section{Resident Representatives: \\ None.}




\section{LESOTHO: ThE JMAP BANK-FUND MATRIX}

(As of February 28, 2011)

\begin{tabular}{|c|c|c|c|}
\hline Title & Products & $\begin{array}{l}\text { Provisional Timing of } \\
\text { missions }\end{array}$ & $\begin{array}{l}\text { Expected Delivery } \\
\text { date }\end{array}$ \\
\hline \multicolumn{4}{|c|}{ A. Mutual information on relevant work programs } \\
\hline $\begin{array}{l}\text { Bank work } \\
\text { program in next } \\
12 \text { months }\end{array}$ & $\begin{array}{l}\text { - Third Poverty Reduction Support } \\
\text { Credit } \\
\text { - Private Sector competitiveness and } \\
\text { Economic Diversification project } \\
\text { - Water Sector Improvement Project } \\
\text { Phase } 2 \\
\text { - Public Expenditure Review } \\
\text { - Governance and Public Sector } \\
\text { Efficiency Review }\end{array}$ & $\begin{array}{l}\text { - February } 2011 \\
\text { - Ongoing regular } \\
\text { missions } \\
\text { - Ongoing regular } \\
\text { missions } \\
\text { - February } 2011 \\
\text { - February } 2011\end{array}$ & $\begin{array}{l}\text { - April } 2011 \\
\text { - Project effective, } \\
\text { implementation } \\
\text { ongoing } \\
\text { - Project effective, } \\
\text { implementation } \\
\text { ongoing } \\
\text { - } 2012 \\
\text { - June } 2011\end{array}$ \\
\hline $\begin{array}{l}\text { IMF work } \\
\text { program in next } \\
12 \text { months }\end{array}$ & $\begin{array}{l}\text { - Program reviews and } 2010 \text { Article IV } \\
\text { Consultation }\end{array}$ & $\begin{array}{ll}\text { - } & \text { May } 2011 \\
\text { - } & \text { November } 2011\end{array}$ & $\begin{array}{l}\text { - July } 2011 \\
\text { - February } 2012\end{array}$ \\
\hline \multicolumn{4}{|c|}{ B. Requests for work program inputs } \\
\hline $\begin{array}{l}\text { Fund request to } \\
\text { Bank }\end{array}$ & $\begin{array}{l}\text { - Updates on policy reform work: } \\
\text { improving the business climate, } \\
\text { economic diversification, private } \\
\text { sector competitiveness and } \\
\text { development, PPP capacity building, } \\
\text { increasing revenue efficiency } \\
\text { - Updates on budget support programs }\end{array}$ & $\begin{array}{l}\text { - Ongoing } \\
\text { - Ongoing }\end{array}$ & \\
\hline $\begin{array}{l}\text { Bank request to } \\
\text { Fund }\end{array}$ & $\begin{array}{l}\text { - Data and macro framework (including } \\
\text { the underlying analytical model). } \\
\text { - Report on the Fund TA on IFMIS }\end{array}$ & $\begin{array}{l}\text { - Regularly } \\
\text { - Regularly }\end{array}$ & \\
\hline \multicolumn{4}{|c|}{ C. Agreements on joint products and missions } \\
\hline $\begin{array}{l}\text { Joint products } \\
\text { in next } 12 \\
\text { months }\end{array}$ & $\begin{array}{l}\text { - Low income debt sustainability } \\
\text { analysis } \\
\text { - JSAN }\end{array}$ & $\begin{array}{l}\text { - May } 2011 \\
\text { - April/May } 2011\end{array}$ & $\begin{array}{l}\text { - July } 2011 \\
\text { - July } 2011\end{array}$ \\
\hline
\end{tabular}




\section{Lesotho: Statistical ISSUES}

The statistical database is adequate for surveillance, although there are some deficiencies in core surveillance data, including government finance and balance of payments statistics that are currently being addressed by the authorities.

As one of 22 countries participating in the GDDS Project for Anglophone African Countries (funded by the U.K. Department for International Development (DFID)), Lesotho has undertaken the GDDS as framework for the development of its national statistical system and a depository of metadata for main macroeconomic aggregates. GDDS metadata have been posted on the Fund's Dissemination Standards Bulletin Board since August 2003. Pending metadata updates in GDDS include those referring to recent/prospective revisions of the national accounts, government finance, and balance of payments statistics.

\section{National accounts}

Revised national accounts were released in November 2008 by the Bureau of Statistics of Lesotho (BSL). Technical assistance from the EU and DFID supported the data revision and the rebasing of the GDP data from 1981 to 2007. Important new sources of data include the use of VAT records and consumer spending information from the 2002/03 household budget survey. Annual GDP estimates in current prices and volume terms from the production, expenditure, and income sides are currently being produced and published by the BLS, albeit with different time lags. Other macroeconomic indicators, such as highfrequency industrial production/trade indices, are used to monitor developments during the year.

There is a need to further improve the source data used for compiling national accounts. Pending challenges include, inter alia, robust data on intermediate consumption for key economic activities, intra-SACU exports and imports, and gross fixed capital formation in machinery and equipment, and formal and informal construction activities. Private consumption and gross fixed capital formation are now estimated within the framework of a supply and use table. However, it has not been possible to balance supply and use completely, hence the remaining discrepancy between the tables on GDP by activity and expenditure.

\section{Prices}

The consumer price index (CPI) is estimated on a monthly basis by the Bureau of Statistics (BOS). The CPI is designated to show changes in the cost of buying a fixed bundle of consumer goods and services as determined for the base period (March 2010) using spending weights from the 2002/03 Household Budget Survey (HBS). Prices are collected every month in twelve urban towns and forty five selected rural areas of Lesotho by personal visits to outlets. 
Plans are in place at the BOS to develop producer and export price indices. In the meantime, the national accounts rely heavily on the South African producer price index (PPI), which is used as a deflator for imports from SACU member countries. South Africa's import price indices are used as deflators for imports from non-SACU countries.

\section{Government finance statistics}

Data on government finance statistics are provided by the Ministry of Finance and Development Planning (MoFDP) to AFR periodically, and the timeliness and quality of the data have improved. Technical assistance from STA and the Development and Implementation of a Macroeconomic Model for Lesotho project (DIMMOL) supported migration of data from GFSM 1986 to the GFSM 2001 framework. AFR has been provided with monthly, quarterly and annual disaggregated central government data (on a cash basis) using the GFSM 2001 framework. These statistics were compiled from the GOLFIS and the Integrated Financial Management Information System (IFMIS), supplemented with data from the Lesotho Revenue Authority (LRA), other government departments and units and the banking system.

The Integrated Financial Management Information System (IFMIS), introduced in April 2009, and which has modules consistent with the GFSM 2001 framework, is now the main source of government finance statistics. However, as a result of teething problems experienced with the IFMIS, there has been inadequate data capture of revenues and budget execution data, and therefore shortcomings to the data to prepare the budget. Steady progress has been made, with technical assistance from the EU and FAD, to improve the functionality of the IFMIS. To ensure timely reconciliation of and monitoring of budget execution, further improvements are needed, including improving revenue tracking and ensuring proper reconciliation and adequate quality check of data from line ministries and government units. The authorities have integrated the government payroll system (Unique, implemented in September 2009) and the CS-DRMS - the public debt recording and management system with the IFMIS, and are working to integrate the LRA system - the VIPS. There are also plans to interface IFMIS with the CBL.

The MFDP also provides annual data to STA on the operations of the general government for publication in the Government Finance Statistics Yearbook. No high frequency data are reported for publication in the International Financial Statistics. The MFDP disseminates government finance statistics, including government debt, to the public through its website and the website of the Bureau of Statistics.

\section{Monetary and financial statistics}

Since December 2004, Lesotho has been compiling monetary statistics based on the Standardized Report Forms (SRFs), which allow for an improved classification and sectorization of accounts. Monthly data using SRFs are currently disseminated in the International Finance Statistics Supplement. 
Despite the progress achieved, the authorities need to expand the institutional coverage of the other depository corporations sector. A monetary and financial statistics mission in September 2007 found that work had started on the inventory of all financial corporations (deposit-taking and others), and that it was expected that credit cooperatives would be fully covered in the other depository corporations' survey.

\section{Balance of payments and external debt}

In 2010, the CBL adopted a new balance of payments database, developed as part of a DIMMOL project to develop an integrated and consistent set of sector flow-of-funds accounts. The development of the external sector account, which began in 2008, benefited from technical assistance from STA. The new database addresses a number of data and methodological classification issues, including the treatment of SACU transfers. The new database provides an opportunity to improve the format of the quarterly and annual balance of payments statements published by the CBL.

Most of the recommendations made by the 2008 STA mission for improving the quality of balance of payments statistics have been implemented in the new database. A STA mission in April/May 2010 reviewed the balance of payments database and confirmed that it is consistent with the standard presentation recommended by the Balance of Payments Manual, fifth edition (BPM5) and that it meets the need of both the balance of payments and the external accounts. The mission welcomed the work of the DIMMOL, which enables access to other sector accounts, such as fiscal and national accounts, providing data sources that supplement data entered directly into the balance of payments database by the CBL. Following from the 2008 recommendations, private capital flows surveys have become an annual survey and the reports published. The 2008 recommendations for expanding the coverage of International Investment Position (IIP) statistics have not yet been implemented.

The mission emphasized the need for staff training to manage the new database; adoption of the new balance of payments database as the official source; and expansion of IIP coverage to reflect available data sources. On dissemination practices, the mission urged the authorities to publish balance of payments and IIP data consistent with BPM5 in the CBL's Annual Report and Quarterly Review and post the balance of payments and IIP data at the CBL website on a quarterly basis.

Data on public sector external debt is provided by the MFDP. The MoFDP maintains a comprehensive database of outstanding loans, with information on currency composition, debt service and amortization, as well as scheduled future disbursements. 


\section{Lesotho: Table of Common Indicators Required for Surveillance}

(As of February 28, 2011)

\begin{tabular}{|c|c|c|c|c|c|}
\hline & $\begin{array}{c}\begin{array}{c}\text { Date of } \\
\text { latest } \\
\text { Observation }\end{array} \\
\end{array}$ & $\begin{array}{l}\text { Date } \\
\text { Received }\end{array}$ & $\begin{array}{c}\text { Frequency } \\
\text { of } \\
\text { Data } 7 / \\
\end{array}$ & $\begin{array}{c}\text { Frequency } \\
\text { of } \\
\text { Reporting } 7 /\end{array}$ & $\begin{array}{l}\text { Frequency of } \\
\text { Publication } 7 /\end{array}$ \\
\hline Exchange rates & Feb. 2011 & Feb. 2011 & $\mathrm{D}$ & M & $\mathrm{D}$ \\
\hline $\begin{array}{l}\text { International reserve assets and reserve liabilities } \\
\text { of the monetary authorities } 1 /\end{array}$ & Feb. 2011 & Feb. 2011 & M & Q & Q \\
\hline Reserve/base money & Dec. 2010 & Feb. 2011 & M & Q & Q \\
\hline Broad money & Dec. 2010 & Feb. 2011 & M & Q & Q \\
\hline Central bank balance sheet & Dec. 2010 & Feb. 2011 & M & Q & Q \\
\hline Consolidated balance sheet of the banking system & Dec. 2010 & Feb. 2011 & M & Q & Q \\
\hline Interest rates $2 /$ & Dec. 2010 & Feb. 2011 & M & M & M \\
\hline Consumer price index & Dec. 2010 & Feb. 2011 & M & M & M \\
\hline $\begin{array}{l}\text { Revenue, expenditure, balance and composition of } \\
\text { financing } 3 / \text {-general government } 4 /\end{array}$ & $\mathrm{N} / \mathrm{A}$ & $\mathrm{N} / \mathrm{A}$ & $\mathrm{N} / \mathrm{A}$ & $\mathrm{N} / \mathrm{A}$ & $\mathrm{N} / \mathrm{A}$ \\
\hline $\begin{array}{l}\text { Revenue, expenditure, balance and composition of } \\
\text { financing } 3 / \text { - central government }\end{array}$ & Dec. 2010 & Feb. 2011 & M & I & Q \\
\hline $\begin{array}{l}\text { Stocks of central government and central } \\
\text { government-guaranteed debt } 5 /\end{array}$ & Dec. 2010 & Feb. 2011 & M & 1 & Q \\
\hline External current account balance & Q3 2010 & Nov. 2010 & Q & Q & Q \\
\hline Exports and imports of goods and services & Q3 2010 & Nov. 2010 & Q & Q & Q \\
\hline GDP/GNP & 2009 & Nov. 2010 & A & A & A \\
\hline Gross external debt & Sept. 2010 & Nov. 2010 & M & Q & Q \\
\hline International investment position $6 /$ & Q1 2010 & Aug. 2010 & Q & Q & Q \\
\hline
\end{tabular}

$1 /$ Includes reserve assets pledged or otherwise encumbered as well as net derivative positions.

2/ Both market-based and officially-determined, including discount rates; money market rates; and rates on treasury bills, notes, and bonds.

3/ Foreign, domestic bank, and domestic nonbank financing.

4/ The general government consist of the central government (budgetary funds, extra budgetary funds, and social security funds) and state and local governments.

$5 /$ Including currency and maturity composition.

$6 /$ Includes external gross financial asset and liability positions vis-à-vis nonresidents.

7/Daily (D), weekly (W), monthly (M), quarterly (Q), annually (A), irregular (I); and not available. 
April 4, 2011

\section{IMF Executive Board Completes First Review Under ECF Arrangement for the Kingdom of Lesotho and Approves Disbursement of US\$9 Million}

The Executive Board of the International Monetary Fund (IMF) has completed the first review of the Kingdom of Lesotho's economic performance under the Extended Credit Facility (ECF) arrangement ${ }^{1}$. The Board's decision, which was taken on a lapse of time basis, enables the authorities to draw an additional SDR 5.68 million (US\$9 million), bringing total disbursements under the arrangement to an amount equivalent to SDR 13.5 million (US\$21.4 million). ${ }^{2}$

The ECF-supported program, adopted against the backdrop of a sharp fall in revenues from the Southern African Customs Union, is on track. Lesotho met all of its quantitative performance criteria except for the performance criterion on stock of net international reserves of the Central Bank of Lesotho that was not observed by a small margin. Structural reforms are also progressing. Ongoing successful program implementation will help strengthen Lesotho's resilience to external shocks and foster economic growth and poverty reduction.

The three-year SDR 41.9 million (about US\$61.4 million) ECF arrangement for Lesotho was approved by the IMF's Executive Board on June 2, 2010 (see Press Release No. 10/224). Lesotho joined the Fund in July 1968.

\footnotetext{
${ }^{1}$ The Extended Credit Facility (ECF) has replaced the Poverty Reduction and Growth Facility (PRGF) as the Fund's main tool for medium-term financial support to low-income countries by providing a higher level of access to financing, more concessional terms, enhanced flexibility in program design features, and more focused streamlined conditionality. Financing under the ECF carries a zero interest rate, with a grace period of 51/2 years, and a final maturity of 10 years (http://www.imf.org/external/np/exr/facts/ecf.htm). The Fund reviews the level of interest rates for all concessional facilities every two years.

${ }^{2}$ The Executive Board takes decisions under its lapse of time procedure when it is agreed by the Board that a proposal can be considered without convening formal discussions.
} 